\title{
Influence of Soil Chemistry and Plant Physiology in the Phytoremediation of $\mathrm{Cu}, \mathrm{Mn}$, and $\mathrm{Zn}$
}

\section{Edgar Pinto, ${ }^{1,3}$ Ana A. R. M. Aguiar, ${ }^{2}$ and Isabel M. P. L. V. O. Ferreira ${ }^{1}$}

${ }^{1}$ REQUIMTE/ Departamento de Ciências Químicas, Laboratório de Bromatologia e Hidrologia da Faculdade de Farmácia da Universidade do Porto, Porto, Portugal

${ }^{2}$ REQUIMTE/Faculdade de Ciências da Universidade do Porto, Porto, Portugal

${ }^{3}$ CISA - Centro de Investigação em Saúde e Ambiente. ESTSP-IPP - Escola Superior de Tecnologia da

Saúde do Instituto Politécnico do Porto, Porto, Portugal

Table of Contents

I. INTRODUCTION

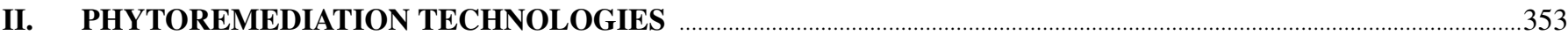

III. PLANT PHYSIOLOGY PROCESSES AFFECTING PHYTOREMEDIATION OF TRACE METALS …..............353

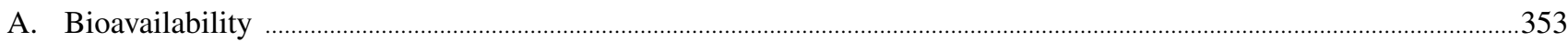

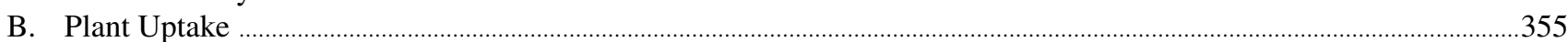

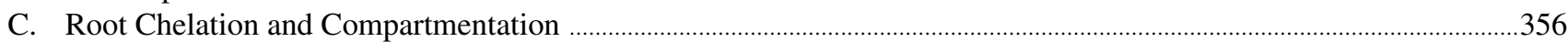

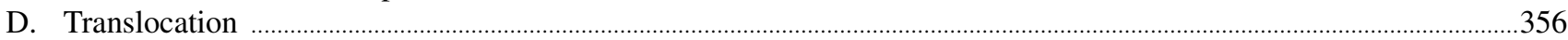

E. Chelation and Compartmentation in Leaves .......................................................................................................................357

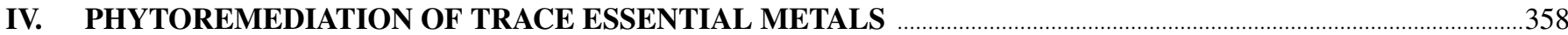

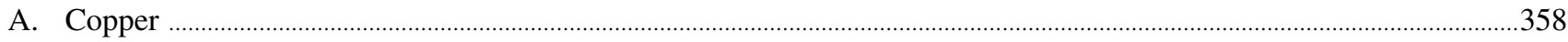

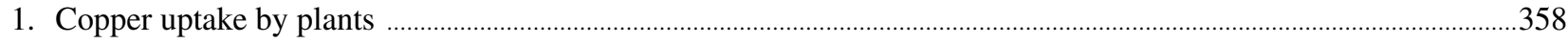

2. Phytoremediation of $\mathrm{Cu}$-contaminated sites ......................................................................................................... 360

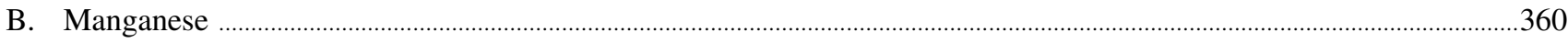

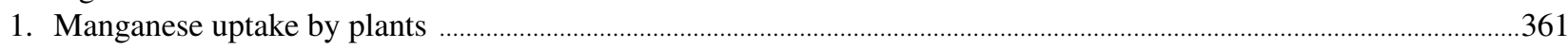

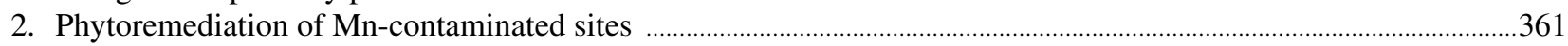

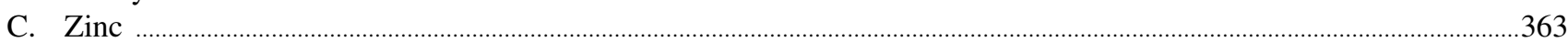

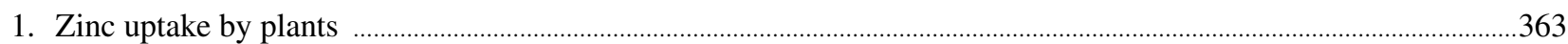

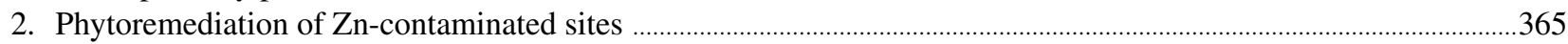

V. STRATEGIES FOR IMPROVING THE PHYTOREMEDIATION OF TRACE ESSENTIAL METALS ................365

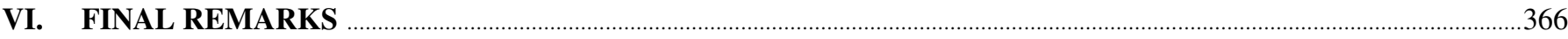

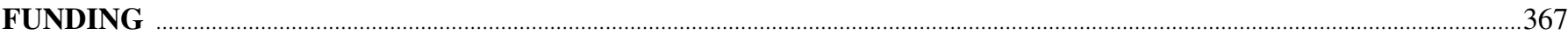

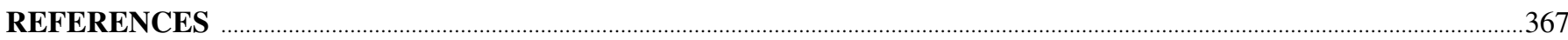


Different anthropogenic sources of metals can result from agricultural, industrial, military, mining and urban activities that contribute to environmental pollution. Plants can be grown for phytoremediation to remove or stabilize contaminants in water and soil. Copper $(\mathrm{Cu})$, manganese $(\mathrm{Mn})$ and zinc $(\mathrm{Zn})$ are trace essential metals for plants, although their role in homeostasis in plants must be strictly regulated to avoid toxicity. In this review, we summarize the processes involved in the bioavailability, uptake, transport and storage of $\mathrm{Cu}, \mathrm{Mn}$ and $\mathrm{Zn}$ in plants. The efficiency of phytoremediation depends on several factors including metal bioavailability and plant uptake, translocation and tolerance mechanisms. Soil parameters, such as clay fraction, organic matter content, oxidation state, $\mathrm{pH}$, redox potential, aeration, and the presence of specific organisms, play fundamental roles in the uptake of trace essential metals. Key processes in the metal homeostasis network in plants have been identified. Membrane transporters involved in the acquisition, transport and storage of trace essential metals are reviewed. Recent advances in understanding the biochemical and molecular mechanisms of $\mathrm{Cu}, \mathrm{Mn}$ and $\mathrm{Zn}$ hyperaccumulation are described. The use of plant-bacteria associations, plant-fungi associations and genetic engineering has opened a new range of opportunities to improve the efficiency of phytoremediation. The main directions for future research are proposed from the investigation of published results.

Keywords phytoremediation, copper, manganese, zinc, soil chemistry, genetic engineering, plant physiology

\section{INTRODUCTION}

In recent decades, the continuous growth of the world population and the quest for material goods has generated a massive expansion in industrial and agricultural production. Demand for food is quickly rising and will continue to rise with increases in global population (Godfray et al., 2010). Since the 1960s, intensive irrigation and massive use of chemical fertilizers and pesticides has allowed an increase in food production obtained from the same amount of land (Vitousek et al., 2009). However, extensive use of mineral fertilizers and pesticides has caused serious contamination of soil and water, decreasing the quality of water and land for human purposes (Melo et al., 2012; Pinto et al., 2010; Quinton et al., 2010; Schwarzenbach et al., 2010). Furthermore, several environmental pollution problems have been observed in cities and urban areas with concentrated population, large energy consumption, and high waste production, traffic emissions and industrial activity (Luo et al., 2012). The continuous pollution of soil, air and water has had a direct adverse impact on ecosystems, cultural heritage, and human health (Phalan et al., 2011).

Soil and water contamination by copper $(\mathrm{Cu})$, manganese (Mn) and zinc ( $\mathrm{Zn})$ has been the subject of several studies in recent decades, and a large database has been already collected and presented in a number of reports. Several significant sources, such as fertilizers, sewage sludge, manure, agrochemicals and industrial by-product wastes, have contributed to the increased $\mathrm{Cu}, \mathrm{Mn}$ and $\mathrm{Zn}$ levels observed in soil and water (Ahmed et al.,
2012; Arthur et al., 2012; Buccolieri et al., 2010; Hu et al., 2009; Testiati et al., 2013).

The complex behavior of metals in the environment is mainly caused by multiple processes occurring in the biosphere over both space and time (Csavina et al., 2012). Physical, chemical and biological interactions that occur between plants and the surrounding environment of the soil are the most complex experienced by land plants. Recent years have seen great advances in the understanding of the complexity of some of these interactions, including the processes involved in nutrient and water uptake by roots under ideal conditions as well as when some nutrients are in short supply (Powlson et al., 2011).

Phytoremediation relies on the use of plants and their associated rhizospheres to degrade, stabilize and/or remove soil contaminants, and it is a technology that has been of greatest interest in recent years. This environmentally friendly and lowcost technology can be used to decontaminate soils, water and sediments containing organic compounds and/or metals (Gerhardt et al., 2009; Kramer, 2010). There is a great interest in applying phytoremediation to agriculture as well as to military and industrial fields that present contamination problems (Andreazza et al., 2011; Mackie et al., 2012; Panz and Miksch, 2012; Pignattelli et al., 2012; Testiati et al., 2013). Polluted waters that can be phytoremediated include sewage and municipal wastewater, agricultural runoff/drainage water, industrial waste water, landfill leachate and mine drainage (Agunbiade et al., 2009; Anning et al., 2013; Boojar and Tavakkoli, 2011; Vaseem and Banerjee, 2012).

Despite all its benefits, phytoremediation has some limitations regarding their specific technologies. For phytoextraction, plants should possess the ability to grow quickly, to produce large amounts of biomass, to be easily harvested and to accumulate a variety of metals in their harvestable parts (shoots). In phytostabilization, plants should have the capacity to retain contaminants in the roots and to produce large amounts of biomass (Andreazza et al., 2011). As yet, no plant is known to fulfill all of these criteria. Limitations on plant growth in sites heavily contaminated with multiple compounds (both organic and inorganic) compromised the efficiency of phytoremediation (Chigbo et al., 2013; Sirguey and Ouvrard, 2013). Thus, the use of transgenic plants could be an important tool to improve some of the characteristics necessary for phytotechnologies. Recent progress in plant physiology, biochemical and molecular fields provides a strong scientific basis for some strategies for achieving this goal (Palmer and Guerinot, 2009; Ramegowda et al., 2012; Tan et al., 2013; Turchi et al., 2012).

The aim of this review is to compile information about plant processes involved in uptake, translocation, and sequestration of $\mathrm{Cu}, \mathrm{Mn}$ and $\mathrm{Zn}$ to improve our understanding of the accumulation process and the distribution of these elements in the plant. The review will focus on the influence of the soil-plant system on phytoremediation. Recent improvements in this technology will be discussed in the field of plant physiology. 


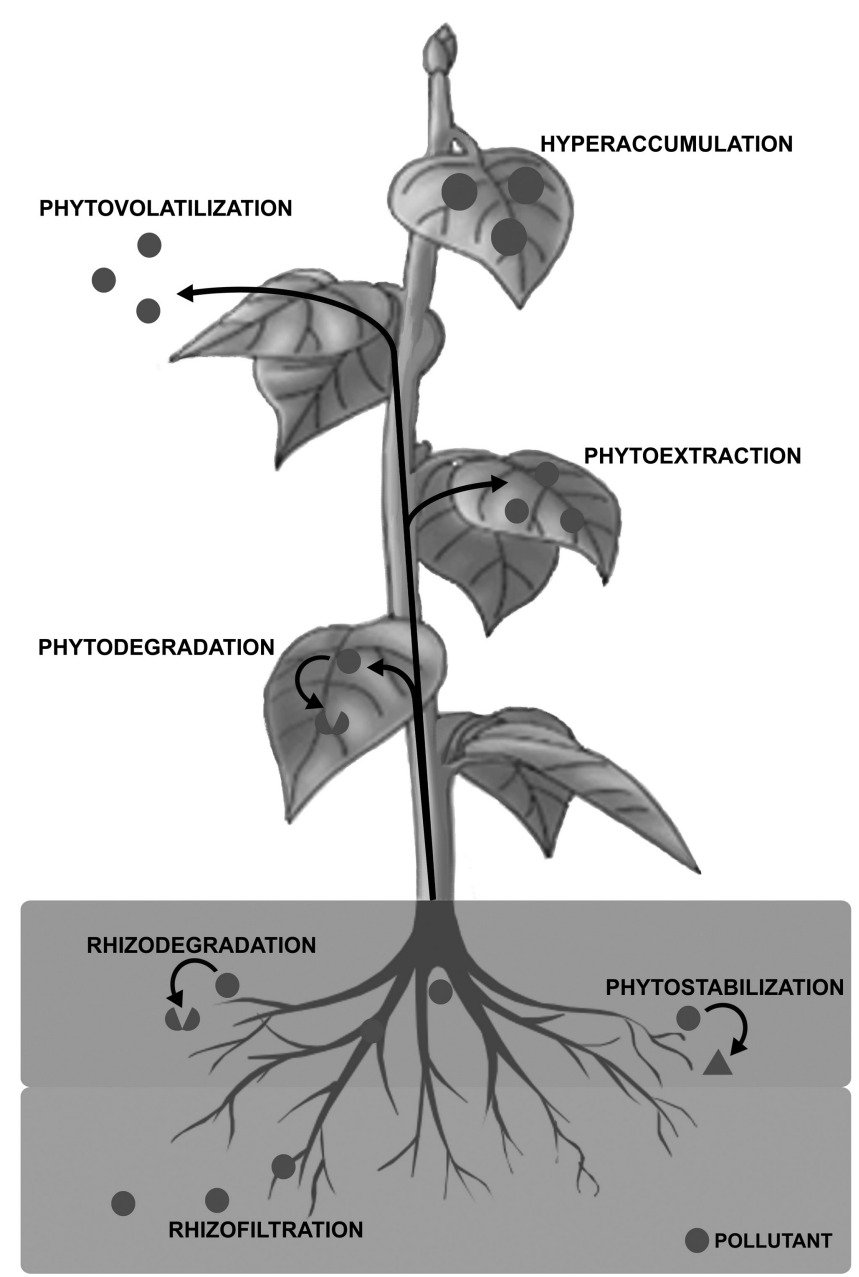

FIG. 1. Schematic presentation of phytoremediation processes.

\section{PHYTOREMEDIATION TECHNOLOGIES}

Plants can be used for phytoremediation in different ways (Figure 1) including removal of contaminants from water and aqueous waste streams in constructed wetlands or filtering pollutants through the root systems of hydroponically cultivated plants, a process called rhizofiltration (Chandra and Yadav, 2011; Valderrama et al., 2012). Deep-rooted species, such as trees, can be used to provide a hydraulic barrier and plume containment through evapotranspiration, creating an upward water flow in the root zone and preventing the spread of contamination (Dominguez et al., 2009). Phytostabilization, another phytotechnology, uses plants to stabilize pollutants in soil, preventing erosion, leaching or runoff, or by converting pollutants to less bioavailable forms. In this process, plants act as a ground cover, reducing animal contact with contaminants present in soil (Dasgupta-Schubert et al., 2011; Pignattelli et al., 2012; Van Nevel et al., 2011).

Rhizodegradation is the ability of a plant to promote the enzymatic breakdown of organic pollutants by microbes in its rhizosphere (Slater et al., 2011). Similarly, plants can degrade organic pollutants directly via their own enzymatic activities, a process called phytodegradation (Panz and Miksch, 2012). After uptake into plant tissue, certain inorganic and organic pollutants are capable of being volatilized; this process is called phytovolatilization (Dhillon et al., 2010). Phytoextraction involves the use of plants to extract pollutants by the roots and transport them to aerial plant organs. Pollutants accumulated in stems and leaves are then harvested and removed from the site (Wu et al., 2012b).

The phytotechnologies are not mutually exclusive, and they are often used in combinations such as degradation, accumulation, and volatilization. Because the phytoremediation process is natural, plants clean our environment constantly, without human interference (Gerhardt et al., 2009; Kramer, 2010).

Desirable plant properties for phytoremediation are fast growth, high biomass, competitiveness, hardiness, and tolerance of pollution. Different phytoremediation technologies are suitable for different classes of pollutants; typically, different plant species are used for each process, as summarized in Table 1.

\section{PLANT PHYSIOLOGY PROCESSES AFFECTING PHYTOREMEDIATION OF TRACE METALS}

The efficiency of phytoremediation depends on several factors: trace metal bioavailability, trace metal uptake, translocation mechanisms, tolerance mechanisms (compartmentation), trace metal chelation and the movement of trace metals through ecosystems.

\section{A. Bioavailability}

As summarized in Figure 2, bioavailability of trace metals depends on environmental conditions such as oxidation state, moisture and temperature, soil properties such as soil organic matter (SOM) and soil $\mathrm{pH}$, and biological activity promoted by microorganisms (Bravin et al., 2012; Gadd, 2010; Yang et al., 2012).

Cation exchange capacity (CEC) is influenced by the concentration of SOM and soil $\mathrm{pH}$. This is an important parameter that controls the bioavailability of cations in soil. When soil $\mathrm{pH}$ becomes acid, the bioavailability of cations generally increases due to replacement of cations on soil CEC sites by $\mathrm{H}^{+}$ions. Clayey soils hold more water than sandy soils, and they have more binding sites for ions, especially cations (Vega et al., 2010; Wu et al., 2010). High temperatures accelerate physical, chemical, and biological processes. Precipitation stimulates general plant growth, and higher soil moisture increases the migration of water-soluble trace metals. The bioavailability of trace metals is also altered by biological activity. The microbial community present in the rhizosphere can produce chelators for delivering key plant nutrients and can enhance the availability/mobility of trace metals in the soil (Rajkumar et al., 2012).

The rhizosphere includes the area surrounding the root (approximately $1 \mathrm{~mm}$ ), and it plays an important role in phytoremediation. The physical, chemical, and biological interactions that take place between roots and the surrounding environment 
TABLE 1

Phytoremediation technologies suitable for different classes of pollutants and favorable plant species for each process

\begin{tabular}{|c|c|c|c|c|}
\hline Phytotechnologies & Type of pollutants & $\begin{array}{l}\text { Favorable plant } \\
\text { properties }\end{array}$ & Plant species & Reference \\
\hline Rhizofiltration & $\begin{array}{l}\text { inorganics (metals, } \\
\text { nitrate, sulfate, } \\
\text { ammonia, phosphate) }\end{array}$ & $\begin{array}{l}\text { Good metal } \\
\text { accumulators, grow } \\
\text { fast, tolerant, attain a } \\
\text { high biomass and can } \\
\text { be harvested easily }\end{array}$ & $\begin{array}{l}\text { Typha angustifólia; } \\
\text { Azolla filiculoides; } \\
\text { Lemna minor; Pistia } \\
\text { stratiotes; Azolla } \\
\text { pinnata }\end{array}$ & $\begin{array}{l}\text { Chandra and Yadav, } \\
2011 \\
\text { Valderrama } \text { et al., } 2012 \\
\text { Vaseem and Banerjee, } \\
2012 \\
\text { Hua } \text { et al., } 2012\end{array}$ \\
\hline Rhizodegradation & $\begin{array}{l}\text { hydrophobic organic } \\
\text { compounds (PCBs, } \\
\text { PAHs and others) }\end{array}$ & $\begin{array}{l}\text { Large root surface area } \\
\text { favors the degradation } \\
\text { process, as it promotes } \\
\text { microbial growth and } \\
\text { the production of } \\
\text { specific exudate } \\
\text { compounds }\end{array}$ & $\begin{array}{l}\text { Salix alaxensis; Picea } \\
\text { glauca; Glycine max; } \\
\text { Oryza sativa; Medicago } \\
\text { sativa }\end{array}$ & $\begin{array}{l}\text { Slater } \text { et al., } 2011 \\
\text { Panz and Miksch, } 2012 \\
\text { Gerhardt } \text { et al.,2009 }\end{array}$ \\
\hline \multirow[t]{3}{*}{ Phytoextraction } & $\begin{array}{l}\text { Trace metals (As, Co, } \\
\mathrm{Cu}, \mathrm{Mn}, \mathrm{Ni}, \mathrm{Pb}, \mathrm{Se}, \mathrm{Zn} \\
\text { and others) }\end{array}$ & $\begin{array}{l}\text { High levels of plant } \\
\text { uptake, translocation, } \\
\text { and accumulation in } \\
\text { harvestable tissues } \\
\text { (hyperaccumulation } \\
\text { occurs when } \\
\text { concentration in } \\
\text { above-ground tissues is } \\
\text { between } 0.1-1 \% \text { of } \\
\text { the plant dry weight) }\end{array}$ & $\begin{array}{l}\text { Arachis pintoi; Zea } \\
\text { mays; Brassica alba; } \\
\text { Oryza sativa }\end{array}$ & $\begin{array}{l}\text { Andreazza et al., } 2011 \\
\text { Murakami and Ae, } \\
2009\end{array}$ \\
\hline & & & Hyperaccumulators: & Kramer, 2010 \\
\hline & & & $\begin{array}{l}\text { Phytolacca americana } \\
(\mathrm{Mn}) ; \text { Alyssum } \\
\text { bertolonii }(\mathrm{Ni}, \mathrm{Co}) ; \\
\text { Noccaea caerulescens } \\
(\mathrm{Cd}, \mathrm{Zn}, \mathrm{Ni}, \mathrm{Pb}) ; \\
\text { Arabidopsis halleri } \\
(\mathrm{Cd}, \mathrm{Zn}) ; \text { Sedum } \\
\text { alfredii, Arabis } \\
\text { paniculata }(\mathrm{Zn})\end{array}$ & $\begin{array}{l}\text { Liu } \text { et al., 2010b } \\
\text { Tang et al., } 2009 \\
\text { Deinlein } \text { et al., } 2012\end{array}$ \\
\hline Phytodegradation & $\begin{array}{l}\text { organics that are mobile } \\
\text { in plants (herbicides, } \\
\text { TPHs, TNT, BTEX and } \\
\text { RDX) }\end{array}$ & $\begin{array}{l}\text { Large, dense root } \\
\text { systems and high levels } \\
\text { of degrading enzymes }\end{array}$ & $\begin{array}{l}\text { Phalaris arundinacea; } \\
\text { Lolium perenne; } \\
\text { Abutilon avicennae; } \\
\text { Phragmites australis }\end{array}$ & $\begin{array}{l}\text { Panz and Miksch, } 2012 \\
\text { Gerhardt } \text { et al.,2009 }\end{array}$ \\
\hline Phytovolatilization & $\begin{array}{l}\text { Volatile organic } \\
\text { compounds (TCE and } \\
\text { MTBE) and few } \\
\text { inorganics (Se and } \mathrm{Hg} \text { ) }\end{array}$ & $\begin{array}{l}\text { High transpiration rate } \\
\text { facilitates the } \\
\text { movement of these } \\
\text { compounds through the } \\
\text { plant }\end{array}$ & $\begin{array}{l}\text { Triticum aestivum; } \\
\text { Brassica napus; Vigna } \\
\text { sinensis; Saccharum } \\
\text { officcinarum; Populus } \\
\text { tremula } \times \text { Populus alba }\end{array}$ & $\begin{array}{l}\text { Dhillon et al., } 2010 \\
\text { Gerhardt } \text { et al.,2009 }\end{array}$ \\
\hline Phytostabilization & $\begin{array}{l}\text { organic and inorganic } \\
\text { pollutants }\end{array}$ & $\begin{array}{l}\text { High transpiration } \\
\text { prevent leaching and } \\
\text { runoff and deep-rooted } \\
\text { grasses prevent the loss } \\
\text { of top soil and } \\
\text { sediments }\end{array}$ & $\begin{array}{l}\text { Quercus robur; Pinus } \\
\text { sylvestris; Pseudotsuga } \\
\text { menziesii; Silene } \\
\text { paradoxa; Aldama } \\
\text { dentata }\end{array}$ & $\begin{array}{l}\text { Nevel } \text { et al., } 2011 \\
\text { Dasgupta-Schubert } \\
\text { et al., } 2011 \\
\text { Pignattelli } \text { et al., } 2012\end{array}$ \\
\hline
\end{tabular}




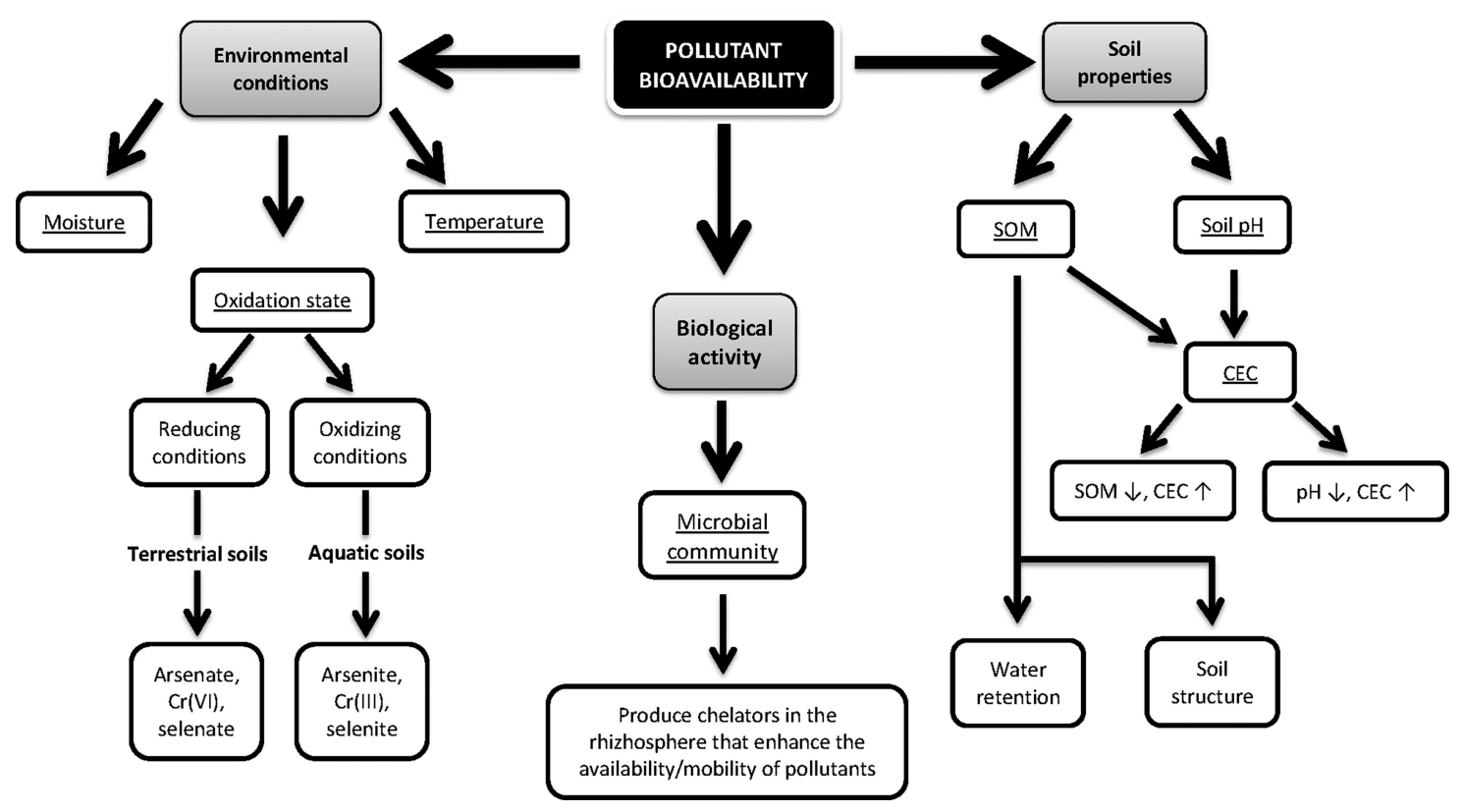

FIG. 2. Schematic diagram of the parameters that can influence pollutant bioavailability. SOM - soil organic matter; CEC - cation exchange capacity.

are largely controlled or directly influenced by roots and are often referred as rhizosphere processes. These include water uptake, exudation, nutrient mobilization, rhizosphere respiration, and rhizosphere-associated SOM decomposition (Cheng, 2009). The bioavailability of trace metals is highly dependent on the rhizosphere processes. Plants and their associated microorganisms can exude compounds that can enhance the uptake of trace metals or reduce their mobility in soil (Hinojosa et al., 2010). For example, in aged polluted soils, the less or nonbioavailable trace metals tend to be more persistent than trace metals in newly contaminated soil, making phytoremediation more difficult to apply (Donner et al., 2012).

Amendments may be added to soil that make metal cations more bioavailable for plant uptake (Wu et al., 2012a). For instance, the effects of five amendments (EDDS, histidine, citric acid, rhamnolipid and sulfate) on the phytoextraction of $\mathrm{Cu}$ have been evaluated. The authors concluded that the combination of two or more amendments was effective for improving phytoremediation of metal contaminated sites by Lolium perenne $(\mathrm{Gu}-$ nawardana et al., 2011). However, care should be taken when applying amendments to improve trace metal bioavailability because leaching to groundwater and thus groundwater pollution can occur (Perez-Esteban et al., 2013).

Furthermore, rhizosphere processes may also be optimized to improve the phytoremediation efficiency. If a certain exudate compound that stimulates microbial degradation is found to enhance phytoremediation, plants and/or microorganisms can be selected or genetically engineered for use in remediation (Slater et al., 2011; Techer et al., 2011).

\section{B. Plant Uptake}

Trace metals enter the root either by crossing the plasma membrane of the root endodermal cells (symplastic transport) or by entering the root apoplast through the space between cells (apoplastic transport). They cannot pass through membranes without the aid of membrane transporter proteins. These transporter proteins occur naturally in several plant membranes (tonoplast, endoplasmic reticulum, mitochondria, chloroplasts) because trace metals are either nutrients $(\mathrm{Cu}, \mathrm{Mn}, \mathrm{Zn})$ or are chemically similar to nutrients and are taken up involuntarily (e.g., $\mathrm{Cd}$ can be taken up by $\mathrm{Zn}$ transporters) (Leitenmaier and Kupper, 2011; Pilon et al., 2009). Plants possess multiple transporters for most elements. For instance, rice (Oryza sativa) has at least seven $\mathrm{Cu}$ transporters (Yuan et al., 2011). Each transporter has unique properties. When a low concentration of nutrients is present in the soil solution, their uptake usually requires a highaffinity transporter. By contrast, low-affinity transporters are more useful when high concentrations of nutrients are present, such as in agricultural soils after fertilization. Furthermore, the abundance of each transporter varies with tissue type and environmental conditions, making the uptake and movement of nutrients in plants complex processes (Cailliatte et al., 2010; Vert et al., 2009).

The accumulation of trace metals in tissues can cause toxicity by damaging the cell structure (e.g., stunting and chlorosis) and/or via replacement of other essential nutrients (Zhao et al., 2012). Combinations of trace metals and organic pollutants may exert either alleviating or exacerbating effects on plant growth, depending on plant species, plant growth stage, the 
concentrations and properties of pollutants, and soil conditions such as $\mathrm{pH}$ and OM content (Chigbo et al., 2013).

Depending on the type of phytoremediation, uptake of trace metals into the plant may be desirable, in the case of phytoextraction, or not, when phytostabilization is to be applied. In those situations, the selection of suitable plant species with the desired properties should be carefully considered (Murakami and Ae, 2009; Testiati et al., 2013). Studies performed under similar conditions are a useful strategy to compare the uptake characteristics of different species for different trace metals (Chehregani et al., 2009). Furthermore, phytoremediation efficiency can be enhanced through several types of changes such as by increasing oxygen levels in roots through aeration which may facilitate or difficult metal uptake (Zhao et al., 2009) or by improving soil nutrient levels through fertilization in order to promote plant growth and thus trace metal uptake (Erenoglu et al., 2011).

\section{Root Chelation and Compartmentation}

Plants and their associated microbial community can release compounds in the root/rhizosphere zone that play crucial roles in tolerance, sequestration, and transport of trace metals (Rajkumar et al., 2012), as summarized in Figure 3.

Most plant-associated microorganism can produce siderophores in response to low $\mathrm{Fe}$ levels in the rhizosphere. These low-molecular-weight chelators play an important role in enhancing extracellular solubilization of Fe from minerals, making it available to the plant-microbial consortium (Schalk et al., 2011). In addition to Fe, other trace metals, such as $\mathrm{Cu}, \mathrm{Mn}$ and $\mathrm{Zn}$, are also able to stimulate or inhibit siderophore production. Additionally, toxic metals may induce the production of some siderophores that have chelator capacity and can play a role in toxic metal tolerance (Braud et al., 2010).

Organic acids released by plant-associated microbes also play an important role in the uptake of trace metals into roots as well as their roles in transport, sequestration, and tolerance of trace metals. In general, organic acids can bind trace metal ions in soil solution by complexation reactions, making them more available for plant uptake (Wang and Zhong, 2011). However, organic acids can also reduce the soil $\mathrm{pH}$ and solubilize some non-labile fraction of trace metals in soil, thus enhancing trace metal availability (Perez-Esteban et al., 2013).

Biosurfactants are another group of important metabolites that have the potential to improve trace metal mobilization and phytoremediation. These amphiphilic molecules have the capacity to form complexes with trace metals at the soil interface and to desorb trace metals from soil matrix, further increasing their solubility and bioavailability in the soil solution (Venkatesh and Vedaraman, 2012).

Other processes based on plant-microbe associations can help promote trace metal mobilization or immobilization. The production of extracellular polymeric substances and glycoproteins (Mikutta et al., 2012), redox reactions (Shi et al., 2011) and biosorption mechanisms (Audet and Charest, 2013; Mrnka et al., 2012) all have the capacity to alter the bioavailability and plant uptake of trace metals through metal mobilizing actions.

Inside the plant, trace metals can be chelated by glutathione (GSH) and phytochelatins (PCs) or metallothioneins (MTs). These chelators have a high affinity for metal cations due to the thiol (-SH) groups on their cysteine residues. After exposure to metal(s), PCs are immediately produced in cells and tissues, though their production is markedly influenced by the type of metal ion present. Phytochelatin synthesis was found to be catalyzed by PC synthase in the presence of metal ions such as $\mathrm{Cu}$ and $\mathrm{Zn}$ (Machado-Estrada et al., 2012). Moreover, this process may work synergistically with secondary stress-defensive antioxidative systems to combat metal induced oxidative stress (Uraguchi et al., 2009; Xu et al., 2011). MTs are also able to bind a variety of trace metals (e.g., $\mathrm{Cu}$ and $\mathrm{Zn}$ ) and to activate antioxidative enzyme defenses (Turchi et al., 2012). Polyphenols and cell wall proteins and pectins are also involved in trace metal chelation and tolerance (Colzi et al., 2012; Schmidt et al., 2013).

After chelation, trace metals in roots may be stored in the vacuole and/or cell wall or exported to the shoot via the xylem. The vacuole is generally considered to be the main storage site for trace metals in plant cells and vacuolar compartmentalization of trace metals is also a part of the tolerance mechanism (Guo et al., 2012).

\section{Translocation}

Translocation is of interest because some phytoremediation techniques demand the transfer of trace metals from roots to aerial tissues. Translocation from root to shoot first requires a membrane transport step from root symplast into xylem, during which solutes must pass the Casparian strip, a waxy coating that prevents solutes from entering the root xylem from the soil solution or root apoplast (Grebe, 2011; Xu et al., 2011).

Although trace metal transporters are highly specialized in the movement of a certain metal, they can sometimes also translocate different metals because they use the same transport systems to be loaded into the xylem (Uraguchi et al., 2009). Some trace metals are chelated by organic acids, which are involved in trace metal absorption by plant roots, translocation in the xylem, and storage in the vacuole of leaf cells (Larbi et al., 2010; Wang and Zhong, 2011). Trace metals can also be bound by nicotianamine (NA) and mobilized by the yellow strike-like (YSL) family transporters (Chu et al., 2010; Harris et al., 2012). It should be emphasized that the translocation of trace metals is a complex process involving multiple networks between membrane transporters and metals. Specialized proteins can transport elements with similar characteristics (e.g., oxidative state), inducing competition that results in deficiency, toxicity and/or accumulation in the above-ground plant tissues (Barberon et al., 2011; Zimmermann et al., 2009).

Very few of these changes exclusively affect a single element, i.e., changes in a transporter that has high specificity for that element. Most of the above-mentioned changes will affect more 


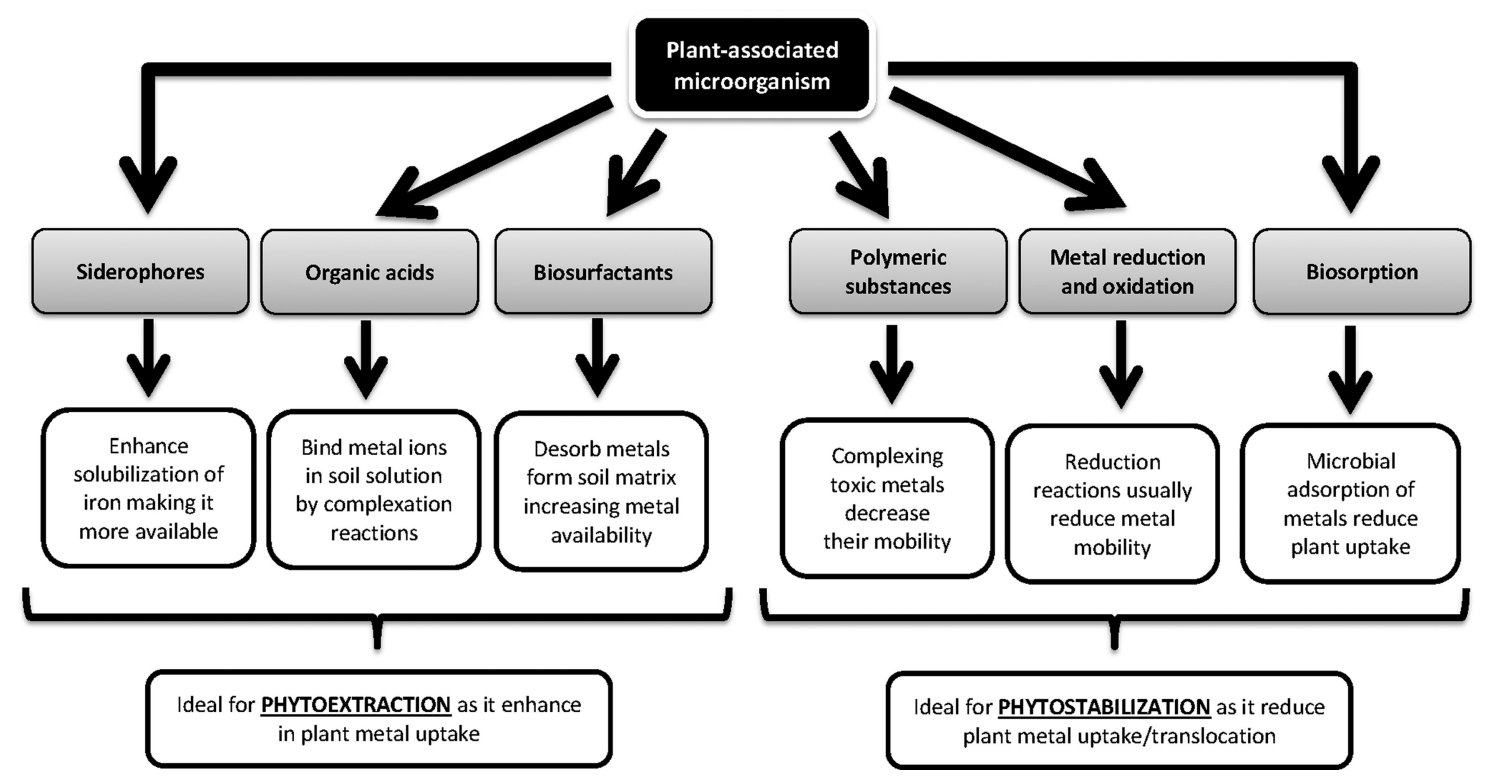

FIG. 3. Schematic diagram of the major plant associations and their roles in phytoremediation. The production of siderophores, organic acids and biosurfactants generally promotes trace metal uptake. The presence of polymeric substances, a reductive medium and biosorption processes reduce trace metal uptake.

than one element. Thus, experiments focused on single elements which do not take into account the total mineral nutrient and trace element content of the plant will not reveal the regulatory networks involved in the homoeostasis of the ionome (Salt et al., 2008).

Transpiration rate is a key variable that determines the rate of chemical uptake for a given phytoremediation application. Bulk flow in the xylem from root to shoot is driven by transpiration from the shoot, which creates a negative pressure in the xylem that pulls up water and solutes. Plant transpiration depends on several aspects of plant species and the surrounding environment. For example, plant metabolic (e.g., C3/C4/CAM photosynthetic pathway) and anatomical differences (e.g., stomatal density) are important factors that affect transpiration rate (Alfonso and Bruggemann, 2012; Orsini et al., 2012). Vegetation height and density, as well as environmental conditions, are also factors to consider (transpiration is normally maximal at high temperature, moderate wind, low relative air humidity, and high light) (Morandi et al., 2012). Therefore, phytoremediation technologies that rely on translocation mechanisms are more efficient in climates with low relative humidity and high evapotranspiration rates.

\section{E. Chelation and Compartmentation in Leaves}

After transport inside the leaf symplast, the trace metal may be stored in certain tissues or cellular organelles. The general rule is that toxic metals are stored in places where they cause the least harm to essential cellular processes. At the tissue level, toxic metals are generally accumulated in the epidermis and trichomes (Sanchez-Pardo et al., 2012); at the cellular level, they may be accumulated in the vacuole or chloroplasts (Boojar and Tavakkoli, 2011).
The distribution of trace metals in leaf tissues is generally asymmetric (Wu and Becker, 2012). Trace metal accumulation in leaf vacuoles makes sense because vacuoles do not contain a photosynthetic apparatus that would be sensitive to metal toxicity (Leitenmaier and Kupper, 2011). Trace metal storage occurs also in highly tolerant cells such as the leaf epidermis and the vein bundle sheath, as long as the metal import remains under control. Once the trace metal accumulation exceeds the tolerance threshold of the plant, the metals would be transported to mesophyll cells, which are more sensitive to toxic metals than other cell types, allowing photosynthesis to be threatened (Zhao et al., 2012). At present, the physiological mechanisms involved in the sequestration of trace metals between different leaf tissues remain only partially understood. One possible mechanism is the differential expression of trace metal transporters in the plasma membrane and/or tonoplast between mesophyll and other tissues. In fact, Leitenmaier and Kupper (2011) show that metal storage in leaf epidermis cells is a rate-limiting step in metal hyperaccumulation, but it is not the only process that governs metal accumulation despite its role as an important driving force behind the complex phenomenon of metal hyperaccumulation. Several membrane transporters (e.g., HMA and VIT) have been proposed to play an important role in vacuolar sequestration (Morel et al., 2009; Zhang et al., 2012b).

Although the phytoremediation process mainly involves the uptake and translocation of trace metals from soil or water, air to leaf accumulation of trace metals is also an important entrance pathway (Saebo et al., 2012). Air to leaf transfer can occur by both particulate and gaseous deposition, resulting in different distribution patterns across the leaf. Trace metals may be taken up directly via the stomata or be deposited on the leaf surface (Schreck et al., 2012). Moreover, air to leaf accumulation of 
trace metals can cause various morphological, physiological and biochemical responses that may influence the phytoremediation process (Doganlar and Atmaca, 2011).

\section{PHYTOREMEDIATION OF TRACE ESSENTIAL METALS}

Copper $(\mathrm{Cu})$, manganese $(\mathrm{Mn})$ and zinc $(\mathrm{Zn})$ are trace essential metals for plants. Although they are essential, cellular concentrations of $\mathrm{Cu}, \mathrm{Mn}$ and $\mathrm{Zn}$ must be strictly regulated to avoid deficiency or toxicity. Worldwide soil deficiency of $\mathrm{Cu}$, $\mathrm{Mn}$ and $\mathrm{Zn}$ seems to be more common than potential excess because most soils have a small bioavailable fraction of these metals. However, very high metal concentrations in soils can be found in the literature where such excess was used to evaluate the plant status. Much knowledge has been obtained by comparing the physiology of plants grown under deficient versus toxic conditions. While such studies may provide an understanding of general plant responses to abiotic stress, this type of approach results in little useful information regarding metal homeostasis. In the next sections, the main findings achieved in the last years in the homeostasis of trace essential metals are summarized.

\section{A. Copper}

Copper is an trace essential element for both animals and plants and has an important role in some physiological processes (Stern, 2010). Nevertheless, it becomes toxic at high concentrations (Canning-Clode et al., 2011). In soil, $\mathrm{Cu}$ concentrations range between 20 and $110 \mathrm{mg} \mathrm{kg}^{-1}$. However, in soil solutions, $\mathrm{Cu}$ concentrations range between 30 and $241 \mu \mathrm{g}$ $\mathrm{L}^{-1}$ (Buccolieri et al., 2010; Kim and Owens, 2009; Mackie et al., 2012). The continuous application of various $\mathrm{Cu}$-based products such as pesticides, fertilizers and animal fodder has resulted in increased $\mathrm{Cu}$ concentrations in agricultural soils well above the European guideline limit of $100 \mathrm{mg} \mathrm{kg}^{-1}$ (Arthur et al., 2012). Furthermore, $\mathrm{Cu}$ is a by-product in several industry and mining processes (Ahmed et al., 2012; Testiati et al., 2013).

Copper is present in several forms in soils, including free ions in the soil solution and complexes with other minerals or with organic components (Kasmaei and Fekri, 2012). $\mathrm{Cu}$ is a relatively immobile element in soil and shows relatively little variation in total content across soil profiles. Depending on soil $\mathrm{pH}, \mathrm{Cu}$ may occur as $\mathrm{Cu}^{+}, \mathrm{Cu}^{2+}, \mathrm{CuSO}_{4}, \mathrm{Cu}(\mathrm{OH})_{2}, \mathrm{CuCO}_{3}$, and other forms (Mackie et al., 2012). Generally, increasing the $\mathrm{pH}$ decreases the solubility of $\mathrm{Cu}$ in soil (Wang et al., 2013). Most common forms of $\mathrm{Cu}$ in soil solutions are soluble organic chelates of this metal (Kasmaei and Fekri, 2012; van Schaik et al., 2010). The two major parameters that influence the variability of total $\mathrm{Cu}$ concentration as well as the available $\mathrm{Cu}$ concentration in soil are the CEC and SOM (Bravin et al., 2012; Vega et al., 2010; Wu et al., 2010). Cu mobility is especially reduced in the presence of large mineral colloids in the clay fraction, as the presence of $\mathrm{Fe}$ and $\mathrm{Mn}$ oxides enhances $\mathrm{Cu}$ fixation to the soil components (Komarek et al., 2008). It is widely accepted that $\mathrm{Cu}$ in soil competes with other elements for sorption sites. Therefore, the mineral composition (particularly the content of other metal cations) will influence the availability of $\mathrm{Cu}$ in soil (Merdy et al., 2009). $\mathrm{Cu}$ is not readily leached from the soil horizons due to its high affinity for OM, and it tends to accumulate in surface soils (van Schaik et al., 2010).

\section{Copper uptake by plants}

Figure 4 addresses the main processes that control $\mathrm{Cu}$ distribution within the plant. Because the most bioavailable form of $\mathrm{Cu}$ in soils is $\mathrm{Cu}^{2+}$, root uptake is most often facilitated by reduction. The ferric reductase oxidases FRO1, FRO2, FRO3, FRO4 and FRO5, expressed in Arabidopsis thaliana, seem to be involved in this process (Bernal et al., 2012; Jeong and Connolly, 2009). Cu is likely to enter the cytosol of root cells through a cell surface COPT/Ctr-family transporter. Six members of the Ctr family (COPT1-6), which mediate the influx of $\mathrm{Cu}$, have been identified in Arabidopsis. AtCOPT1, the first COPT family member identified and characterized, is expressed in the plasma membrane of roots and has an important role in the acquisition of $\mathrm{Cu}$ monovalent ions. AtCOPT2 and AtCOPT3 are also present in the plasma membrane of root tissues and seem to play a role in $\mathrm{Cu}$ acquisition from the rhizosphere (Andres-Colas et al., 2010). Furthermore, it is hypothesized that members of the Zinc-Regulated Transporter and Iron-Regulated Transporter (ZRT-IRT)-like proteins (ZIP) family can mediate the uptake and transport of $\mathrm{Cu}$ in both Arabidopsis thaliana and Medicago truncatula (del Pozo et al., 2010; Stephens et al., 2011). Members of the Yellow Stripe family (ZmYS1) are also involved in the transport of $\mathrm{Cu}$-phytosiderophore (PS) complexes (Murata et al., 2008).

The export of $\mathrm{Cu}$ from the root symplast to the xylem requires $\mathrm{Cu}$-transporting P-type ATPases. The P-type ATPases, known as heavy metal P-type ATPases (HMAs) in plants, include at least eight (HMA1-HMA8) identified members in Arabidopsis thaliana. AtHMA1 to AtHMA4 belong to the group implicated in divalent cation transport; AtHMA5 to AtHMA8 act on monovalent $\mathrm{Cu}$ ion transport (Zimmermann et al., 2009; Zorrig et al., 2011). Efflux of $\mathrm{Cu}$ into the vascular tissues is thought to occur through an HMA family transporter. AtHMA5, mostly expressed in roots, flowers and pollen, is likely responsible for root $\mathrm{Cu}$ detoxification. This phenotype function is the opposite of COPT, corroborating the idea that AtCOPT1 and AtHMA5 transport $\mathrm{Cu}$ in opposite directions (del Pozo et al., 2010; Kobayashi et al., 2008). Cu translocation may involve chelators such as the nicotianamine (NA) and several amino acids (Harris et al., 2012; Irtelli et al., 2009). Moreover, $\mathrm{Cu}$ in the xylem sap of rice seems to be bound to deoxymugineic acid (DMA), while in the phloem sap, $\mathrm{Cu}$ mainly complexes with NA and histidine (Ando et al., 2013). Regarding transporters, the recently identified HvYSL2, which is localized in the root endodermis, also seems to be involved in the transport of $\mathrm{Cu}$ 


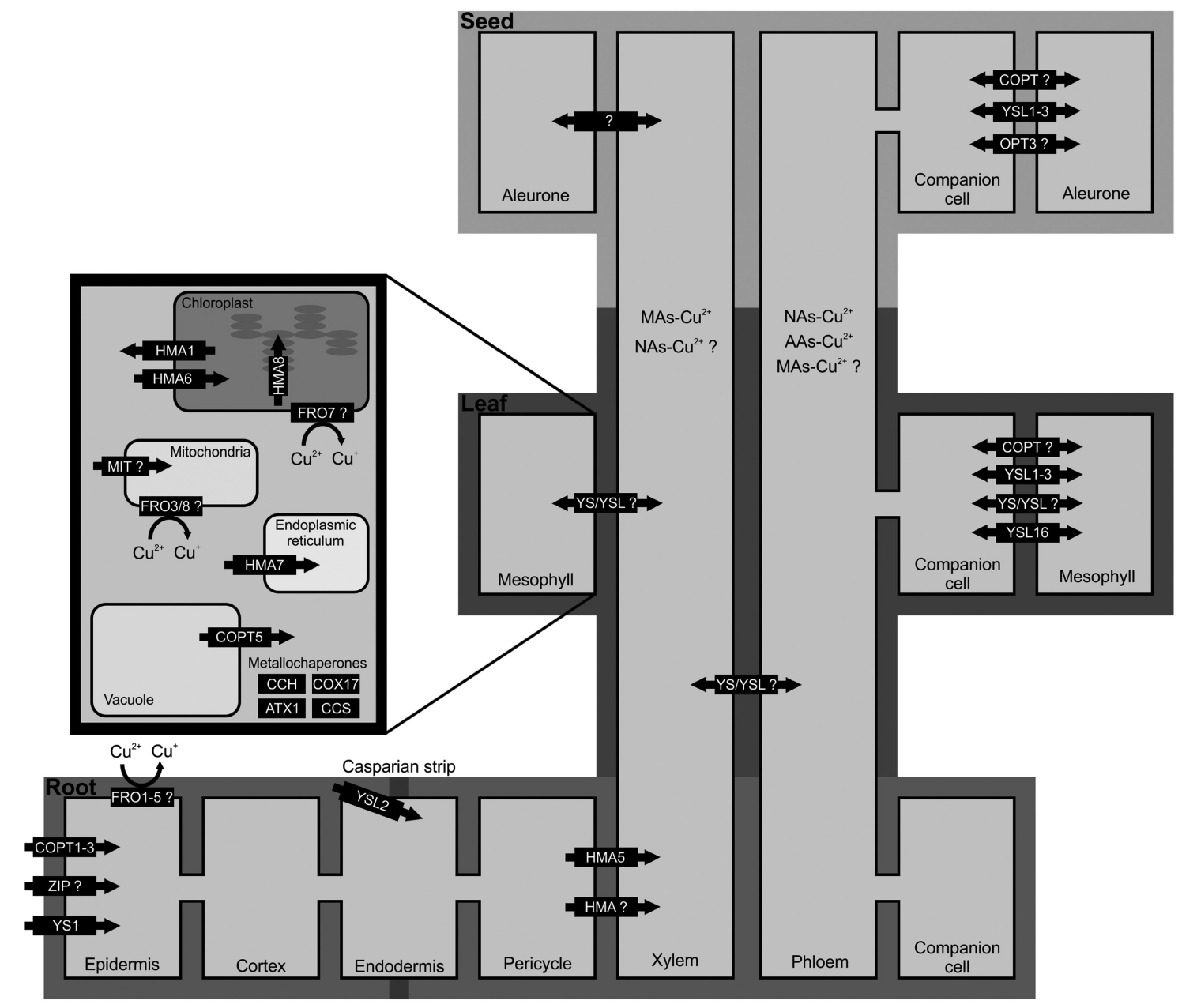

FIG. 4. Copper transport in a model plant. $\mathrm{Cu}$ is taken up into the symplast by transporters in the epidermis in the free form (COPT1-3 and ZIP) and/or complexed with phytosiderophores (YS1). Possible reduction of $\mathrm{Cu}^{2+}$ to $\mathrm{Cu}^{+}$could be performed by FRO1-5. To enter the xylem, Cu must pass the Casparian strip. YSL transporters (e.g., YSL2) appear to have a role in the mobilization of $\mathrm{Cu}$ from the cortex to the pericycle. Transport into the xylem is mediated by members of the HMA family. In the xylem, Cu is thought to be moved in the form of complexes (with MAs and NAs) to the shoot, where they are unloaded, most likely by members of the YSL family. The xylem transport of $\mathrm{Cu}$ to seed is not well characterized. The YSLs may also translocate metals to the phloem, where they can then be delivered to the leaf and seed tissues by various transporters (YSL, COPT, OPT). After transport inside the leaf symplast, Cu may be stored in certain tissues or cellular organelles. If $\mathrm{Cu}$ is present in the divalent form, reduction must be performed before it can enter the cell organelles. FRO7 (expressed in the chloroplasts) and FRO3/8 (expressed in the mitochondria) are hypothesized to have a role in Cu reduction. Members of the HMA family (HMA1 and HMA6) mediate the influx and efflux of $\mathrm{Cu}$ in the chloroplast. Moreover, HMA8 is expressed in the thylakoid membrane and supplies $\mathrm{Cu}$ to plastocyanin. In the mitochondria, $\mathrm{Cu}$ influx is thought to occur via MIT. HMA7 is responsible for supplying $\mathrm{Cu}$ at the endoplasmic reticulum. COPT5 is important for Cu export from the vacuole. Several metallochaperones (ATX1, CCH, COX17, CCS) ensure proper metal delivery to target proteins and maintain Cu homeostasis. (Figure layout based on Palmer and Guerinot, 2009).

(and other metals) from the cortex to the pericycle (Araki et al., 2011). OsYSL16 is a Cu-NA transporter required to deliver $\mathrm{Cu}$ to developing young tissues and seeds through phloem transport (Lee et al., 2012; Zheng et al., 2012). In Arabidopsis root, the plasma membrane AtYSL1 and AtYSL3 were proven to be involved in the root-to-shoot and shoot-to-seed transport of $\mathrm{Cu}$ as well as other metals (Chu et al., 2010; Waters and Grusak, 2008). The COPT-family transporters are also responsible for $\mathrm{Cu}$ uptake in leaves and other shoot organs. In addition to their expression in root, AtCOPT1 and OsCOPT1 also showed high expression in the plasma membrane of leaves supporting the idea of a role in the $\mathrm{Cu}$ transport in shoot (Andres-Colas et al., 2010; Yuan et al., 2011). OsCOPT2 and OsCOPT3 had relatively high expression levels in leaf and panicle (Yuan et al., 2011). In Arabidopsis, COPT6 is expressed in different cell types in different plant compartments, but the bulk of its expression is located in the vasculature (Jung et al., 2012). Similarly, OsCOPT6 is not expressed in root but is highly expressed in leaf, stem and sheath. COPT7 was only found in rice and had relatively high expression levels in leaves; similar responses to OsCOPT5 were observed in both $\mathrm{Cu}$ deficiency and overdose environments (Yuan et al., 2011). Furthermore, the oligopeptide 
transporter AtOPT3 and its orthologue TcOPT3 seem to participate in the mobilization of $\mathrm{Cu}$ (Hu et al., 2012; Stacey et al., 2008).

Again, if $\mathrm{Cu}$ is present in its divalent form, reduction must be performed before it can enter the cell organelles. AtFRO7 (expressed in the chloroplasts) and AtFRO3/8 (expressed in the mitochondria) play a central role in Fe reduction, and it is hypothesized that they also participate in $\mathrm{Cu}$ reduction (Jeong and Connolly, 2009). AtHMA6 (or PAA1), localized in the inner chloroplast envelope, is responsible for the delivery of $\mathrm{Cu}$ to chloroplasts (Catty et al., 2011). AtHMA8 (PAA2), closely related to AtHMA6 (PAA1), is expressed in the thylakoid membrane and supplies $\mathrm{Cu}$ to plastocyanin (Tapken et al., 2012). AtHMA1 and HvHMA1, present in the chloroplast envelope, are broad-specificity exporters of metals from chloroplasts and may play a specialized role in $\mathrm{Cu}$ mobilization (Mikkelsen et al., 2012). AtHMA7 (RAN1), the first functionally characterized heavy metal ATPase, is responsible for the biogenesis of ethylene receptors by supplying $\mathrm{Cu}$ at the endoplasmic reticulum and also for $\mathrm{Cu}$ homeostasis in seedling development (Binder et al., 2010). The rice mitochondrial Fe transporter (MIT) also appears to regulate the influx of $\mathrm{Cu}$, although more studies are needed to confirm this (Bashir et al., 2011). The tonoplastlocalized AtCOPT5 is important for $\mathrm{Cu}$ export from the vacuole and is involved in the remobilization of $\mathrm{Cu}$ ions (Garcia-Molina et al., 2011; Klaumann et al., 2011). Until now, none of the eight identified FRO present in Arabidopsis have been expected to play a role in the reduction process of $\mathrm{Cu}$ on the vacuolar membrane, raising the possibility that other reductase enzymes may function as ferric reductases in plants (Jeong and Connolly, 2009). Finally, several metallochaperones expressed in Arabidopsis (e.g., ATX1, CCH, COX17, CCS) ensure proper metal delivery to target proteins and also maintain $\mathrm{Cu}$ homeostasis, preventing metal toxicity (Puig and Penarrubia, 2009).

Normally, $\mathrm{Cu}$ content ranges from 2 to $50 \mu \mathrm{g} \mathrm{g}^{-1} \mathrm{DW}$, depending on the plant species. However, 5 - $20 \mu \mathrm{g} \mathrm{g}^{-1} \mathrm{DW}$ seems to be optimal, as toxicity symptoms appear above and deficiency symptoms below this critical range (Hansch and Mendel, 2009; White and Brown, 2010). $\mathrm{Cu}$ deficiency/toxicity affects plant physiological processes and ultimately plant production (Ravet et al., 2011; Sanchez-Pardo et al., 2012).

\section{Phytoremediation of $\mathrm{Cu}$-contaminated sites}

Phytoremediation of $\mathrm{Cu}$-contaminated sites can be observed in both soil and water. Regarding water remediation, $\mathrm{Cu}$ accumulation and translocation was observed in the well-known macrophyte Hydrilla verticillata at higher extent. Plant shoots accumulate $\mathrm{Cu}$ to a maximum of $30830 \mu \mathrm{g} \mathrm{g}^{-1}$ DW after exposure to $4 \mathrm{mg} \mathrm{L}^{-1} \mathrm{Cu}$ for 4 days (Xue et al., 2010). The duckweed Lemna minor, the macrophyte Azolla pinnata and the water crowfoot Ranunculus tricophyllus also show accumulation of $\mathrm{Cu}$, suggesting that all three species can be used for remediation of this metal in polluted waters (Vaseem and Banerjee, 2012). Furthermore, Eleocharis acicularis can accumulate a maximum of $20200 \mu \mathrm{g} \mathrm{g}^{-1}$ of $\mathrm{Cu}$ in its shoots, suggesting great potential for use in the phytoremediation of water environments (Sakakibara et al., 2011). The amphibious water plant Crassula helmsii can also hyperaccumulate $\mathrm{Cu}$ (Kupper et al., 2009). Based on the $\mathrm{Cu}$ accumulation of Azolla filiculoides $(6013 \mu \mathrm{g}$ $\mathrm{g}^{-1}$ ), this species can be regarded as a potential phytoremediation organism with high potential for cleaning water polluted with $\mathrm{Cu}$ (Valderrama et al., 2012). In another study, Liu et al. (2010a) compiled information about 19 wetland plant species and concluded that the selection of appropriate plant species in constructed wetland is crucial for the improvement of metal removal efficiency.

The phytoremediation of $\mathrm{Cu}$-contaminated sites has been accomplished by numerous plant species in metal-polluted soils. An area contaminated with metals due to mining activities was phytoremediated by Zygophyllum fabago, which mostly accumulated $\mathrm{Cu}$ in its aerial part, particularly in leaf vacuoles (Boojar and Tavakkoli, 2011). In addition to mining sites, other $\mathrm{Cu}$ contaminated areas such as vineyard soils have also been phytoremediated. The potential of the perennial peanut (Arachis pintoi) was evaluated in those soils, and the authors concluded that this species has high potential for $\mathrm{Cu}$ removal and can be an important candidate for use in the phytoextraction and phytostabilization of vineyard soils contaminated with $\mathrm{Cu}$ (Andreazza et al., 2011). Phytoremediation of $\mathrm{Cu}$-contaminated sites was also performed by Sedum plumbizincicola in agricultural fields (Wu et al., 2012b). Furthermore, maize (Zea mays), white mustard (Brassica alba) and rice (Oryza sativa) also show great potential for $\mathrm{Cu}$ phytoextraction (Brunetti et al., 2012; Murakami and Ae, 2009). Other plants that can be used in the phytoremediation $\mathrm{Cu}$-contaminated sites are Euphorbia prostrate, Dyssodia setifolia, Parthenium incanum, and Zinnia acerosa (MachadoEstrada et al., 2012). Aside from phytoextraction, the stabilization of $\mathrm{Cu}$ by plant species is also a reliable technology for improving soil quality in heavily contaminated sites (Kumpiene et al., 2009; Testiati et al., 2013). The high $\mathrm{Cu}$ storage in the roots of Aldama dentata makes it attractive as a possible $\mathrm{Cu}$ phytostabilizer (Dasgupta-Schubert et al., 2011). The salt-marsh shrub Halimione portulacoides can tolerate external $\mathrm{Cu}$ levels of up to $1000 \mathrm{mg} \mathrm{L}^{-1}$ without suffering adverse physiological effects (Cambrolle et al., 2012). Moreover, the cuprophyte Haumaniastrum katangense was proved to be highly tolerant to $\mathrm{Cu}$ (Chipeng et al., 2010).

\section{B. Manganese}

Typical soil concentrations of Mn vary from 450 to $550 \mathrm{mg}$ $\mathrm{kg}^{-1}$. In soil solution, Mn concentrations are normally between 50 and $2000 \mu \mathrm{g} \mathrm{L}^{-1}$ (Mundus et al., 2012; Rajapaksha et al., 2012). Mn commonly occurs in more than one oxidation state (e.g., $\mathrm{Mn}^{2+}, \mathrm{Mn}^{3+}, \mathrm{MnO}_{4}{ }^{-}$and others). Because $\mathrm{Mn}^{3+}$ is unstable in solution and $\mathrm{Mn}^{4+}$ compounds are slightly soluble, $\mathrm{Mn}^{2+}$ is the only important soluble form of $\mathrm{Mn}$ in soils (Das et al., 2011; Mundus et al., 2012). The soil distribution of Mn is not uniform and is known to be concentrated in certain spots, 
which are usually enriched with other trace elements (Heredia and Cirelli, 2009). The dynamics and availability of soil Mn are determined by many factors such as $\mathrm{pH}, \mathrm{Eh}$, the nature and concentration of cations and anions, clay mineralogical composition, OM content, and microorganisms. Mn availability is higher in acid soils due to the higher solubility of Mn compounds under low-pH conditions (Husson, 2013). Mn oxides show a great affinity for adsorption of both cationic and anionic forms of elements. Thus, Mn oxides have a major impact in the mobilization of trace metals in soils (Manh et al., 2011; Rajapaksha et al., 2012). Mn-oxidizing microbes increase Mn oxidation rates in soils by up to five orders of magnitude, affecting the availability of Mn to plants (Gadd, 2010).

The main sources of Mn for soils are organic manures, chemical fertilizers, and microbial biomass. The principal Mn depletion mechanisms are uptake by crop plants, loss through soil erosion, leaching, and adsorption on organic compounds or microbial biomass (Cheraghi et al., 2012; Geissen et al., 2010). The major anthropogenic sources of $\mathrm{Mn}$ are municipal wastewaters, sewage sludge, and metal smelting processes (Hu et al., 2009; Ning et al., 2010). Mn is widely used in metallurgy as well as in the electrical industry. It also has applications in the production of pigments, ceramics, and glass. Further, methylcyclopentadienyl manganese tricarbonyl (MMT) is used as an octane-enhancing agent (Das et al., 2011; Joly et al., 2011). Certain areas are exposed to higher Mn inputs, leading to environmental as well as human consumption problems (Geissen et al., 2010; McArthur et al., 2012).

\section{Manganese uptake by plants}

The oxidized forms $\mathrm{Mn}^{3+}$ and $\mathrm{Mn}^{4+}$ are not bioavailable to plants and cannot be accumulated. It is the reduced form of this element, $\mathrm{Mn}^{2+}$, that is absorbed by root cells (Mundus et al., 2012). The mechanisms of Mn homeostasis, including uptake, distribution and storage, remain poorly understood. However, some transporters have been identified as participating in the transport of Mn; they are described in Figure 5. The plasma membrane IRT1, expressed in both Arabidopsis and barley, can transport Mn as well as Zn (Barberon et al., 2011; Pedas et al., 2008). Furthermore, overexpressing of AtIRT2 leads to overaccumulation of $\mathrm{Mn}$ in transgenic plants, but the role of this transporter in Mn accumulation remains to be clarified (Vert et al., 2009). The plasma membrane-localized NRAMP1 and NRAMP5 were shown to be high-affinity Mn transporters in Arabidopsis and rice, respectively. Both AtNRAMP1 and OsNRAMP5 have broad selectivity, and their expression is restricted to the root (Cailliatte et al., 2010; Ishimaru et al., 2012). Furthermore, Mn uptake can also be performed by the ZmYS1 transporter, which was confirmed to be capable of acquiring Mn-PS complexes from the rhizosphere (Murata et al., 2008).

The translocation of $\mathrm{Mn}$ involves chelators such as NA, amino acids and carboxylic acids (Harris et al., 2012; Kato et al., 2010). Despite the preference for the transport of $\mathrm{Fe}$ PS complexes, the ZmYS1 transporter is also able to translocate
Mn-chelated species (Murata et al., 2008). OsYSL6 is a Mn-NA transporter that is required for the detoxification of excess $\mathrm{Mn}$ in rice (Sasaki et al., 2011). Likewise, OsYSL2 is involved in Mn translocation in the phloem. In the knockout ys 12 line, seeds and shoots contain lower Mn content compared with the wild-type (Ishimaru et al., 2010). Moreover, the same transporter (YSL2) shows the ability to transport Mn-PS complexes in barley roots (Araki et al., 2011). In Arabidopsis, AtZIP2 seems to participate in Mn transport into the root vasculature for translocation to the shoot (Milner et al., 2013). The oligopeptide transporter AtOPT3 seems to play an important role in the long-distance transport of Mn (Stacey et al., 2008).

After uptake and translocation, Mn must be distributed into various cell compartments. The P-type ATPases AtECA1 (localized at the endoplasmic reticulum) and AtECA3 (expressed in the Golgi complex) participate in the influx of Mn (Li et al., 2008; Mills et al., 2008). The cation/H exchanger (CAX) transporters AtCAX2 and AtCAX4, which were originally identified as $\mathrm{Ca}$ transporters, also have the ability to transport $\mathrm{Mn}$ into the vacuole (Connorton et al., 2012; Korenkov et al., 2007). Likewise, vacuolar $\mathrm{Mn} / \mathrm{H}$ antiporter activity in the Arabidopsis cax2 knockout mutant is significantly reduced compared with wild-type, although it is not completely absent, suggesting the presence of additional vacuolar transporters (e.g., AtCAX5) that contribute to Mn transport (Edmond et al., 2009). AtMTP11, which belongs to the cation diffusion facilitator (CDF) family, is implicated in the pre-vacuolar compartmentation of $\mathrm{Mn}$ as well as in the Mn homeostasis mechanisms (Delhaize et al., 2007). Other MTPs also contribute to Mn transport (Gustin et al., 2011). Furthermore, it seems that the tonoplast-localized transporters OsVIT1 and OsVIT2 participate in Mn influx to the vacuole (Zhang et al., 2012b). Regarding vacuolar export, AtNRAMP3 and AtNRAMP4 are expressed in the tonoplast and can transport Mn and other metals (Lanquar et al., 2010). AtZIP1 probably plays a role in Mn vacuolar efflux, based on the increased sensitivity to low $\mathrm{Mn}$ and increased accumulation of $\mathrm{Mn}$ in roots in the zipl knockout line (Milner et al., 2013). The rice Fe transporter MIT appears to play a role in Mn transport into mitochondria (Bashir et al., 2011). The mechanisms of Mn transport in the chloroplast remain unknown, despite the fact that $\mathrm{Mn}$ has a critical role in photosynthesis and the chloroplast is the one of the major sinks for Mn (Millaleo et al., 2013; Yao et al., 2012).

Mn content is remarkably varied across plant species, growth stage and different organs and ecosystems. Normally, Mn content in plants varies from 10 to $100 \mu \mathrm{g} \mathrm{g}^{-1}$ (Hansch and Mendel, 2009; White and Brown, 2010). Below 10 and above $200 \mu \mathrm{g} \mathrm{g}^{-1}$, Mn deficiency/toxicity occurs and plant physiological processes are compromised (Najeeb et al., 2009; Zhao et al., 2012).

\section{Phytoremediation of Mn-contaminated sites}

Phytoextraction of Mn-contaminated sites can be observed in both soil and water. In water, Mn remediation has been performed by T. latifolia, Scirpus americanus (Santos-Diaz and 


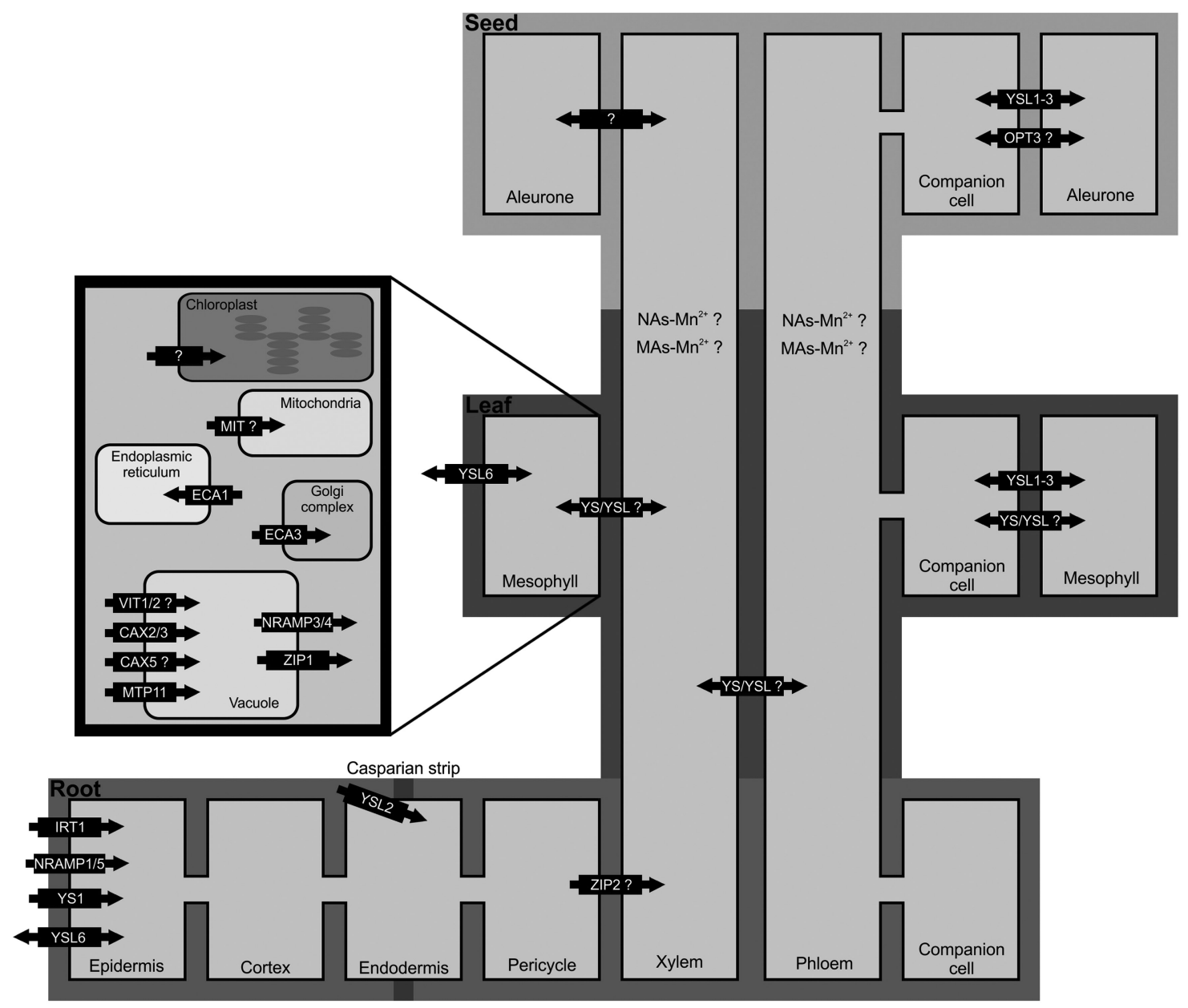

FIG. 5. Manganese transport in a model plant. Mn is taken up into the symplast by membrane transporters in the epidermis in the free form (IRT1 and NRAMP1) and/or complexed with phytosiderophores (YS1). To enter the xylem, Mn must pass the Casparian strip. YSL transporters (e.g., YSL2) appear to have a role in the mobilization of Mn from the cortex to the pericycle. Transport of free Mn into the xylem is thought to occur via members of the ZIP family. In the xylem, Mn is thought to move in the form of Mn-PS complexes to the shoot, where they are unloaded, most likely by members of the YSL family. Xylem transport of Mn is not well characterized. The YSLs may also translocate metals to the phloem, where they can then be delivered to the leaf and seed tissues by various transporters (YS, YSL, OPT). After transport inside the leaf symplast, Mn may be stored in certain tissues or cellular organelles. Manganese transport into mitochondria is hypothesized to occur via MIT. Mn is supplied to the Golgi complex by ECA3 and to the endoplasmic reticulum by ECA1. The transporters CAX2/3 and MTP11 mediate the influx of Mn across the vacuolar membrane into the vacuole. Furthermore, other CAXs (e.g., CAX5) are thought to have a similar role in the influx of Fe into the vacuole, as is VIT1/2. Mn transport into the chloroplast is unknown. (Figure layout based on Palmer and Guerinot, 2009).

Barron-Cruz, 2011), P. cummunis, T. angustifolia, C. esculentus (Chandra and Yadav, 2011), A. caroliniana (Pandey, 2012), Alternanthera philoxeroides, Eichhornia crassipes and P. stratiotes (Agunbiade et al., 2009; Hua et al., 2012). Of those, the water lettuce (P. stratiotes) accumulates high levels of $\mathrm{Mn}$ in both roots and shoots (28290 and $26240 \mu \mathrm{g} \mathrm{g}^{-1}$, respectively) and has been found to meet the characteristics of a good phytoremediator (Lu et al., 2011). Pokeweed (Phytolacca americana) was also able to accumulate high levels of Mn (approximately $20000 \mu \mathrm{g} \mathrm{g}^{-1} \mathrm{DW}$ ) (Dou et al., 2009). Furthermore, two macrophytes, A. pinnata and L. minor, have shown great potential to remediate Mn (Vaseem and Banerjee, 2012).

For Mn phytoremediation in soil, eight plants were evaluated according to their capacity to tolerate or accumulate Mn.
An exclusion strategy was performed with Equisetum hyemale and Telypteris kunthii, while Cnidoscolus multilobus, Platanus mexicana, Solanum diversifolium, Asclepius curassavica and Pluchea sympitifolia were employed for an accumulation strategy. Accumulation of $\mathrm{Mn}$ in plant leaves was in the range of 182 - $1507 \mu \mathrm{g} \mathrm{g}^{-1}$ DW (Juarez-Santillan et al., 2010). In another study, the same Mn tolerance and accumulation mechanism was tested in six species. Of those, the authors found that P. perfoliatum, $P$. hydropiper, and P. americana were Mn hyperaccumulators and that $P$. perforliatum had superior Mn accumulation and tolerance (shoots of $P$. perfoliatum reached $18342 \mu \mathrm{g} \mathrm{g}^{-1}$ ) over the other five species (Liu et al., 2010b). Five woody plants species (T. arjuna, P. juliflora, $P$. alba, E. tereticornis and D. strictus) were evaluated for their capacity to remediate metals 
from tannery sludge dumps. All plants show the capacity to accumulate $\mathrm{Mn}$ in their tissues, but E. tereticornis was considered the most effective plant in the remediation of Mn (Shukla et al., 2011). For phytostabilization purposes, the use of $S$. paradoxa may be suitable due to its low root-to-shoot translocation of $\mathrm{Mn}$ (Pignattelli et al., 2012).

\section{Zinc}

In worldwide soils, total $\mathrm{Zn}$ content ranges between 60 and $100 \mathrm{mg} \mathrm{kg}^{-1}$; and in soil solution range between 20 and $570 \mu \mathrm{g}$ $\mathrm{L}^{-1}$ (Behera et al., 2011). In soil solution, Zn occurs as both free and complexed ions such as $\mathrm{Zn}^{2+}, \mathrm{ZnNO}_{3}{ }^{+}, \mathrm{ZnOH}^{+}, \mathrm{ZnHCO}_{3}{ }^{+}$, $\mathrm{ZnSO}_{4}$ and $\mathrm{Zn}\left(\mathrm{HPO}_{4}\right)$, which are the most common and mobile $\mathrm{Zn}$ species in soil. Zn-organic species may also occur in soil solution (Stephan et al., 2008). The soil-plant system is highly dynamic, and the availability of elements such as $\mathrm{Zn}$ is altered due to physical, chemical, and biological changes. The main factors that control the mobility of $\mathrm{Zn}$ in soils are very similar to those mentioned for $\mathrm{Cu}$ and $\mathrm{Mn}$, and they include $\mathrm{pH}, \mathrm{SOM}$, Eh, CEC, the type and concentration of ionic species, carbonate content, particle-size distribution and presence of oxide and hydroxide species. By lowering the soil $\mathrm{pH}$, the adsorption of $\mathrm{Zn}$ is reduced, resulting in the mobilization and leaching of $\mathrm{Zn}$. By increasing the Eh in soils, $\mathrm{Zn}$ is shifted from unstable to more stable fractions, thus decreasing its mobility (Yang et al., 2012). Clay fraction and SOM are capable of immobilizing $\mathrm{Zn}$, especially at neutral and alkaline $\mathrm{pH}$ values (Luo et al., 2011; Zhong et al., 2011). Concentrations of $\mathrm{Zn}$ in the soil particle fractions tended to increase with decreasing particle size (Ghiri et al., 2012). The presence of other ionic species in the soil can influence the mobility of $\mathrm{Zn}$ in soil (Jalali and Zinli, 2012). Moreover, oxides and hydroxides of $\mathrm{Al}, \mathrm{Fe}$, and $\mathrm{Mn}$ seem to be important for binding $\mathrm{Zn}$ in soils (Zhao et al., 2011).

Zinc is widely used in many industry activities. It is a major component of alloys, batteries, automobile equipment, pipes, and household devices, and it is used as catalyst in the production of rubber, pigments, plastic, lubricants, and pesticides (Wilkinson et al., 2011). Despite the usual low concentrations of $\mathrm{Zn}$ in soil, the content of this element can rise to several thousands of $\mathrm{mg} \mathrm{kg}^{-1}$ due to anthropogenic activities such as agricultural practices and industry and mining activities (Ahmed et al., 2012; Buccolieri et al., 2010). Water pollution by $\mathrm{Zn}$ is more notable near industry zones due to waste discharges. Leaching of $\mathrm{Zn}$ can occur due to its mobility in soil, increasing water contamination (Gonzalez-Fernandez et al., 2011; Yi et al., 2011).

\section{Zinc uptake by plants}

The homeostasis of $\mathrm{Zn}$ in plants is a complex process. The major mechanisms involved in this process are described in Figure 6. $\mathrm{Zn}$ is readily available to plants in its soluble forms, including water-soluble $\mathrm{Zn}$, exchangeable $\mathrm{Zn}$ and $\mathrm{Zn}$ adsorbed to colloids/OM surface. However, the soluble fraction accounts for less than $10 \%$ of total soil Zn content (Kim et al., 2010). Therefore, solubilization of tightly bound $\mathrm{Zn}$ is necessary, and it seems to occur by the acidification of the rhizosphere and the secretion of chelating species (Li et al., 2011; Widodo et al., 2010). Then, $\mathrm{Zn}$ is taken up across the plasma membrane of root cells as a free ion and/or complexed with phytosiderophores (Ptashnyk et al., 2011; Suzuki et al., 2008). The ZIP transporter family includes the best candidates for facilitating $\mathrm{Zn}$ influx into the plant cytoplasm. In addition to its role in Fe acquisition, AtIRT1 is also responsible for the uptake of $\mathrm{Zn}$ from the soil solution (Fukao et al., 2011). The broad selectivity of AtIRT1 allows this transporter to mediate the uptake of several divalent metal cations, including Zn (Barberon et al., 2011; Shanmugam et al., 2011). This was also demonstrated in rice plants overexpressing OsIRT1, which accumulate elevated levels of $\mathrm{Zn}$ in the shoots, roots and mature seeds (Lee and An, 2009). Like their close homolog IRT1, IRT2 and IRT3 are also able to transport Zn into roots. Arabidopsis overexpressing IRT2 and IRT3 accumulated more $\mathrm{Zn}$ than did wild-type plants (Lin et al., 2009; Vert et al., 2009). Other ZIP transporters are involved in the uptake of $\mathrm{Zn}$ from soil. For example, OsZIP1 and OsZIP3 are likely to play a role in $\mathrm{Zn}$ uptake from soil (Bashir et al., 2012). In Arabidopsis, ZIP4 expression is induced upon $\mathrm{Zn}$ deficiency, showing its function as a $\mathrm{Zn}$ transporter (Assunção et al., 2010). The high affinity of the divalent metal transporters MtZIP5 and MtZIP6 suggest a role in the uptake of $\mathrm{Zn}$ from the rhizosphere (Stephens et al., 2011). This trend was confirmed in a similar study, in which overexpression of OsZIP5 improved Zn uptake from the soil (Lee et al., 2010a). ZIP8, localized in the plasma membrane of rice, seems to be a $\mathrm{Zn}$ transporter that functions in Zn uptake (Lee et al., 2010b). Furthermore, AtNRAMP1 is also able to transport $\mathrm{Zn}$ from the soil (Cailliatte et al., 2010). $\mathrm{Zn}$ is also transported from the rhizosphere in the form of Zn-PS complexes by ZmYS1, although its orthologue in barley, HvYS1, is not able to perform this transport (Murata et al., 2008).

Zinc is exported from root by two members of the P-type ATPase family, HMA2 (expressed in Arabidopsis, rice and barley) and HMA4 (Mills et al., 2012; Takahashi et al., 2012; Wong and Cobbett, 2009). However, other transporters can also perform the export of $\mathrm{Zn}$ to vascular tissues. In Arabidopsis, pcr2 lossof-function mutants accumulate $\mathrm{Zn}$ in roots, suggesting a role of in root-to-shoot translocation of $\mathrm{Zn}$, independent of HMA2 and HMA4 (Song et al., 2010). Furthermore, it was proved that AtFRD3 is involved in loading $\mathrm{Zn}$ into xylem (Pineau et al., 2012). Zn can also be exported from the roots in the form of $\mathrm{Zn}$ complexes. Before export from the roots, $\mathrm{Zn}$ must be mobilized to pericycle cells, apparently by HvYSL2 (Araki et al., 2011). After xylem loading, $\mathrm{Zn}$ can be transported to aboveground tissues by the YS and YSL transporters. There is some evidence that AtYSL1, AtYSL2 and AtYSL3 can be involved in the transport of $\mathrm{Zn}$ (Chu et al., 2010). Phytosiderophores such as NA and DMA are important in the distribution of $\mathrm{Zn}$ within the plant (Harris et al., 2012; Nishiyama et al., 2012; Suzuki et al., 2008). Although until now no Zn-PS transporters have been identified, the presence of these complexes in the xylem and phloem sap suggests that members of the YSL family may 


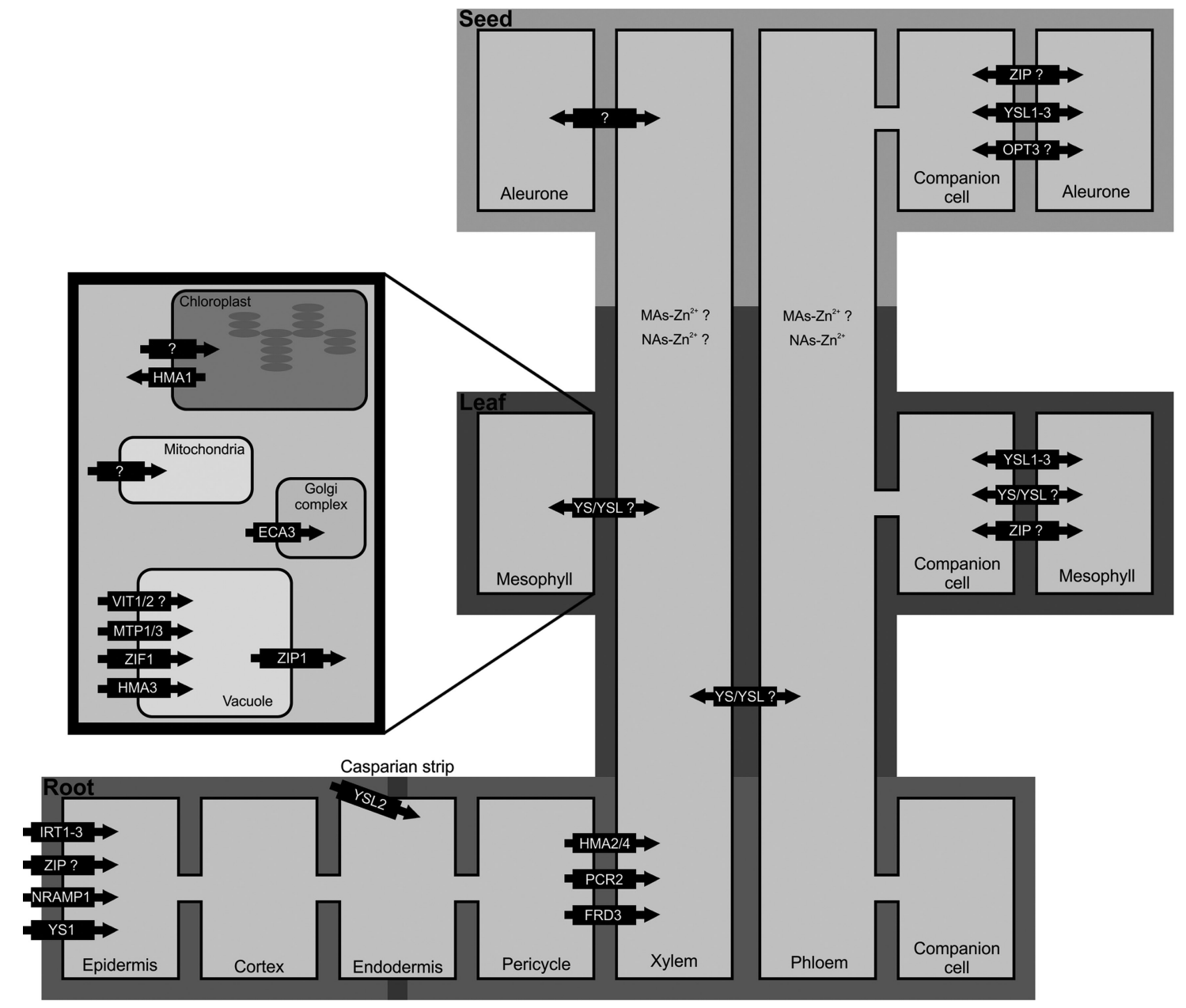

FIG. 6. Zinc transport in a model plant. Zn is taken up into the symplast by membrane transporters in the epidermis as a free cation (IRT1-3, NRAMP1 and ZIP) and/or complexed with phytosiderophores (YS1). To enter the xylem, Zn must pass the Casparian strip. YSL transporters (e.g., YSL2) appear to have a role in the mobilization of $\mathrm{Zn}$ from the cortex to the pericycle. Transport of free $\mathrm{Zn}$ into the xylem is thought to occur via the HMA2/4, PCR2 and FRD3. In the xylem, Zn is thought to move in the form of Zn-PS complexes to the shoot, where they are unloaded, most likely by members of the YSL family. Xylem transport of Zn is not well characterized. The YSLs may also translocate metals to the phloem, where they can then be delivered to the leaf and seed tissues by various transporters (ZIP, YS, YSL, OPT). After transport inside the leaf symplast, Zn may be stored in certain tissues or cellular organelles. Zn transport into mitochondria has not been characterized. The supply of $\mathrm{Zn}$ to the Golgi complex is performed by ECA3. The transporters HMA3, ZIF1 and MTP1/3 mediate the influx of Zn across the tonoplast into the vacuole. Furthermore, both VIT1 and VIT2 are thought to have a similar role in the influx of Fe into the vacuole. The efflux of Zn from the vacuole appears to be performed by ZIP1. Zn influx to the chloroplast is unknown, but its efflux is mediated by HMA1. (Figure layout based on Palmer and Guerinot, 2009).

be involved in the transport of $\mathrm{Zn}$ complexes (Deinlein et al., 2012; Rellan-Alvarez et al., 2008). Moreover, members of the ZIP family are expressed in the vascular bundle, suggesting that they contribute to the distribution of $\mathrm{Zn}$ along the plant (Bashir et al., 2012). AtOPT3 and its orthologue TcOPT3 seem to participate in the long-distance transport of $\mathrm{Zn}$ (Hu et al., 2012; Stacey et al., 2008).

The delivery of $\mathrm{Zn}$ to plant organelles is also mediated by specific transporters. The vacuolar membrane transporter AtMTP1 and its orthologue HvMTP1 have an essential role in detoxification of excessive $\mathrm{Zn}$. When grown in excessive $\mathrm{Zn}$, the mutant line of Arabidopsis that lacks MTP1 was not able to accumulate $\mathrm{Zn}$ in vacuoles, unlike wild-type roots (Kawachi et al., 2009; Podar et al., 2012). AtMTP3 is also localized in the tonoplast, where it contributes to basic cellular $\mathrm{Zn}$ tolerance and controls $\mathrm{Zn}$ partitioning (Arrivault et al., 2006). Similarly, AtHMA3 seems to play a role in the detoxification of Zn by participating in its vacuolar sequestration (Morel et al., 2009). It has been speculated that ZIF1 is involved in a mechanism of Zn sequestration. Specifically, AtZIF1 has been implicated in the transport of Zn complexes (mainly with NA) into the vacuole, as overexpression of ZIF1 leads to strongly enhanced vacuolar 
Zn accumulation (Haydon et al., 2012). The tonoplast-localized OsVIT1 and OsVIT2 seem to transport $\mathrm{Zn}$ into the vacuoles of plant cells (Zhang et al., 2012b). AtZIP1 may contribute to remobilizing $\mathrm{Zn}$ from the vacuole to the cytoplasm (Milner et al., 2013). In the chloroplasts of both Arabidopsis and barley, HMA1 contributes to $\mathrm{Zn}$ detoxification by exporting $\mathrm{Zn}$ from the plastids to the cytoplasm (Kim et al., 2009; Mikkelsen et al., 2012). It has been proposed that the Golgi-localized transporter AtECA3 may have a role in the mobilization of $\mathrm{Zn}$ from the cytoplasm to the Golgi complex (Barabasz et al., 2011; Mills et al., 2008).

In most crops, the optimal $\mathrm{Zn}$ content ranges between 15 and $50 \mu \mathrm{g} \mathrm{g}^{-1}$ DW (Hansch and Mendel, 2009; White and Brown, 2010). Below $15 \mu \mathrm{g} \mathrm{g}^{-1}$, plants exhibit $\mathrm{Zn}$ deficiency symptoms. $\mathrm{Zn}$ toxicity is usually observed when plant $\mathrm{Zn}$ content is above $100 \mu \mathrm{g} \mathrm{g}^{-1}$ (Hajiboland and Amirazad, 2010; Zhao et al., 2012).

\section{Phytoremediation of Zn-contaminated sites}

The phytoremediation of $\mathrm{Zn}$-contaminated sites can be performed in soil and water. In water, phytoremediation of $\mathrm{Zn}$ is well performed by E. crassipes, which achieves a 95\% removal of this metal (Mishra and Tripathi, 2009). Similar percentages of $\mathrm{Zn}$ removal were also observed when A. pinnata and L. minor were used (Vaseem and Banerjee, 2012). Other plant species such as T. latifolia (Sasmaz et al., 2008), C. ligulata, J. imbricatus (Miguel et al., 2013), E. acicularis (Ha et al., 2009), P. cummunis, T. angustifolia, C. esculentus (Chandra and Yadav, 2011) and P. stratiotes (Lu et al., 2011) have shown potential to remediate $\mathrm{Zn}$-contaminated waters.

In soil, phytoremediation of $\mathrm{Zn}$ can be conducted by several plant species. Some examples are Pennisetum americanum $\times$ Pennisetum purpureum, Paspalum atratum (Zhang et al., 2010), Z. fabago (Boojar and Tavakkoli, 2011), Betula pendula, Robinia pseudoacacia, Populus tremula (Van Nevel et al., 2011), Noea mucronta (Chehregani et al., 2009), Glycine max (Murakami and Ae, 2009) and Salix smithiana (Puschenreiter et al., 2013). Hyperaccumulation of $\mathrm{Zn}$ can also be observed. A wild population of Arabis paniculata was shown to be hypertolerant of extremely high concentrations of $\mathrm{Zn}$ and could accumulate an average of $20800 \mu \mathrm{g} \mathrm{g}^{-1}$ of this element in its shoots (Tang et al., 2009). Furthermore, plants such as Arabidopsis halleri, Sedum alfredii and Noccaea caerulescens are widely known Zn hyperaccumulators (Deinlein et al., 2012; Kramer, 2010). Phytostabilization of $\mathrm{Zn}$ is also a viable technology for application in contaminated soils, and several plants have been well established to perform this task. For example, the perennial shrub Sesbania virgata is an excellent species for use in $\mathrm{Zn}$ contaminated soils (Branzini et al., 2012). Other plant species that are good candidates for phytostabilization are Quercus robur, Quercus petraea, Pinus sylvestris, Pseudotsuga menziesii (Van Nevel et al., 2011) and S. paradoxa (Pignattelli et al., 2012).

\section{STRATEGIES FOR IMPROVING THE PHYTOREMEDIATION OF TRACE ESSENTIAL METALS}

Aging of soil promotes the immobilization of $\mathrm{Cu}, \mathrm{Mn}$ and $\mathrm{Zn}$ by shifting these elements from labile to non-labile fractions. The reduction of the available fraction of these trace metals is one of the major constraints of phytoremediation efficiency (Donner et al., 2012). Moreover, the application of phytoremediation in heavily contaminated soils may become very difficult because plants cannot yield sufficient biomass and/or withstand the metal stress in such severe conditions (Sirguey and Ouvrard, 2013). To surpass such limitations, several strategies have been proposed, including the application of amendments, the use of bacteria and fungi associated with plants and the application of genetic engineering to improve plant processes.

To improve the phytoremediation of $\mathrm{Cu}, \mathrm{Mn}$ and $\mathrm{Zn}$, the application of amendments (organics and inorganics) has been widely studied and has proven to be a useful way to manage some of the problems related to trace metal bioavailability and plant growth (Gunawardana et al., 2011; Najeeb et al., 2009; Perez-Esteban et al., 2013). Amendments can be used to enhance the bioavailability of trace metals, which will improve phytoextraction, or to reduce the labile fraction of trace metals, to assist in phytostabilization (Padmavathiamma and Li, 2010; Wu et al., 2012a).

Another way to improve the phytoremediation of $\mathrm{Cu}, \mathrm{Mn}$ and $\mathrm{Zn}$ relies on the use of endophytic bacteria. Endophytes are microbes that live inside plant tissues without causing harm to the host and can facilitate plant growth as well as increase resistance to pathogens, drought and herbivores (Rajkumar et al., 2012). Plant growth-promoting bacteria can be exploited for promoting plant biomass production and metal phytoremediation in contaminated soils (Andreazza et al., 2010; Kumari and Singh, 2011). In addition to bacteria, the arbuscular mycorrhizal fungi (AMF) are also involved in phytoremediation of $\mathrm{Cu}, \mathrm{Mn}$ and $\mathrm{Zn.} \mathrm{AMF} \mathrm{are} \mathrm{ubiquitous} \mathrm{terrestrial} \mathrm{symbionts} \mathrm{involving} \mathrm{func-}$ tioning parts of plants living in mutualistic association with the fungi (Meier et al., 2012). Symbiotic mycorrhizal associations can increase the efficiency of phytoremediation due to improvements in the uptake and delivery of nutrients to the plant and in tolerance to metal toxicity (Bissonnette et al., 2010; Cornejo et al., 2013; Hernandez-Ortega et al., 2012). For example, the nonpathogenic Fusarium fungus was able to increase $S$. alfredii root system function, metal availability and accumulation, plant biomass, and thus $\mathrm{Zn}$ phytoextraction efficiency (Zhang et al., 2012a).

Phytoremediation of $\mathrm{Cu}, \mathrm{Mn}$ and $\mathrm{Zn}$ can also be improved by controlling the biochemical processes that occur inside and outside the plant at the cellular and molecular level. The expression of specific membrane transporters in transgenic plants that are responsible for metal uptake, translocation and storage is currently being used to improve phytoremediation processes. The expression of OsZIP1 in finger millet and tobacco (Nicotiana tabacum) results in significantly higher accumulation of $\mathrm{Mn}$ and 
Zn (Ramegowda et al., 2012). Overexpression of TaHMA2 in rice increased the elongation and decreased the seed-setting rate and root-to-shoot Zn translocation (Tan et al., 2013). Heterologous expression of AhHMA4 in tomato facilitates root-to-shoot Zn translocation and induces Zn uptake (Barabasz et al., 2012). Similarly, expression of AtHMA4 in tobacco could be a candidate transporter for engineering modifications of $\mathrm{Zn}$ translocation (Siemianowski et al., 2011). The Golgi-localized AtECA3 was introduced into tobacco, resulting in better growth of the plants and enhanced tolerance of high $\mathrm{Mn}$ and $\mathrm{Zn}$ concentrations (Barabasz et al., 2011). Further, the expression of AtCAX2 or AtCAX4 in Nicotiana tabacum results in enhanced tolerance of Mn (Korenkov et al., 2007). The chelation capacity of PCs and MTs to detoxify metals in plant can also be improved through plant engineering (Machado-Estrada et al., 2012; Vurro et al., 2011). The overexpression of phytochelatin synthase 1 (PtPCS1) in poplar results in a two-fold increase of $\mathrm{Zn}$ accumulation in leaf tissues (Adams et al., 2011). Transgenic poplar lines expressing MT type 2 gene (PsMTA1) from Pisum sativum show increases in the ability to translocate and accumulate $\mathrm{Cu}$ during metal stress without a significant increase in reactive oxygen species (Turchi et al., 2012). Transgenic tobacco expressing EhMT1 (metallothionein type 1 protein from Elsholtzia haichowensis) shows high tolerance to and accumulation of $\mathrm{Cu}$ and a more efficient antioxidant system, suggesting that MT1 should be considered as a potential candidate for enhancement of $\mathrm{Cu}$ tolerance in plants (Sekhar et al., 2011). In the same way, the metallothionein type 1 protein from Cajanus cajan (CcMT1) was expressed in Arabidopsis thaliana, resulting in higher accumulations of $\mathrm{Cu}$ and providing a marked tolerance of metal stresses (Sekhar et al., 2011). Another metallothionein (pCeMT) was isolated from Colocasia esculenta and overexpressed in tobacco, which exhibited enhanced $\mathrm{Cu}$ tolerance and accumulation and better growth compared with control (Kim et al., 2013). Moreover, the biosynthesis of other metal chelators such as NA and DMA can be improved to enhance metal accumulation in different plant parts. The overexpression of the barley NA synthase HvNAS1 in rice showed increases in endogenous phytosiderophore content in shoots, roots, and seeds, resulting in higher $\mathrm{Zn}$ levels in rice seeds (Masuda et al., 2009). Similarly, overexpression of OsNAS2 in rice results in a 16-fold increase in the total content of $\mathrm{Zn}$ complexes with both NA and DMA. Moreover, high levels of NA inside the plant led to greater exudation of PS from the roots, thereby stimulating Zn uptake, translocation and seed-loading (Lee et al., 2011). Finally, the expression of genes from non-plant organisms can also improve the phytoremediation efficiency. Transgenic Arabidopsis overexpressing the yeast transcription factor ACE1 increased the activity levels of superoxide dismutase and peroxidase, benefiting the cell in response to toxic levels of $\mathrm{Cu}$ (Xu et al., 2009). Transgenic poplar plants expressing the heavy metal resistance gene ScYCF1 (yeast cadmium factor 1) showed enhanced growth, reduced toxicity symptoms, and increased Zn content (Shim et al., 2013).

\section{FINAL REMARKS}

In recent years, phytoremediation has arisen as a practical, low cost and environmentally friendly technology. It is considered the best approach for removing metal pollution. The major drawbacks of metal phytoextraction processes are the bioavailability of the target metal(s) and the ability of plants to accumulate metals within their aboveground biomass at levels well above their nutrient requirements. Recent research in the field of phytoextraction has been focused on finding the ideal metal-accumulating plants and metal uptake and translocation mechanisms. Currently, several plant species are known to hyperaccumulate $\mathrm{Cu}, \mathrm{Mn}$ and $\mathrm{Zn}$. Although metal hyperaccumulation in plants is poorly understood, outstanding progress has been made in the last few years to understand the biochemical and molecular mechanisms of that process.

During the last few years, several reports of attempts to increase metal bioavailability through the addition of various amendments have been published. Although this approach often works on a laboratory scale, it is much less effective in the field. The use of plant-bacteria associations to improve metal phytoremediation can significantly help the growth of plants in the presence of high (and often phytotoxic) levels of metals, but the bacteria typically do little or nothing to increase metal phytoavailability. However, bacterially assisted phytoremediation is a recent technology, and better understanding of how different types of bacteria contribute to phytoremediation is needed. Regarding plant-fungi associations, there is plenty of evidence in the literature that demonstrates the important role of these associations in promoting plant status in metal-polluted soils. Although there have been recent advances in understanding the physiological mechanisms behind these associations, more investigation is needed to ascertain their functional compatibility and to prove their efficiency in promoting phytoremediation.

Key processes in the metal homeostasis network whose alteration drastically modifies metal tolerance and distribution in plant tissues have been identified. Several genes (e.g., COPT, ZIP, NAS, YSL, HMA) have been functionally cloned, and their importance in metal accumulation has been established. More broadly, genetic engineering has opened a new range of opportunities for understanding metal hyperaccumulation and hypertolerance. Though much remains to be learned about $\mathrm{Mn}$ and Zn uptake, transport and homeostasis, a full understanding of $\mathrm{Cu}$ homeostasis is near. In addition, an integrative approach using diverse plant species will lead to a better understanding of metal uptake, transport and distribution. Although there is limited evidence for coordination of the regulatory networks that control $\mathrm{Cu}, \mathrm{Mn}$ and $\mathrm{Zn}$ homeostasis in plants, there is some crosstalk. Because different metals use the same transporters, there is clear evidence for interaction. For example, the IRT1 transporter performs both $\mathrm{Mn}$ and $\mathrm{Zn}$ uptake; therefore, these metals affect each other's uptake. Moreover, low Fe leads to IRT upregulation, which in turn allows more $\mathrm{Zn}$ uptake. Zn toxicity may therefore be a secondary effect of Fe deficiency. Other membrane transporters have the same capacity to transport 
different metals, so a complex coordination process is thought to occur.

Many of the challenges in plant metal homeostasis, from uptake to storage, have been overcome. There is significant evidence that the regulation of metal ion homeostasis is mediated by membrane transporters. A multigene strategy must be carried out by the use of modern molecular techniques to further understand the complex regulatory processes in plants in order to improve metal accumulation in high biomass nonhyperaccumulator species useful for phytoremediation. More work is necessary to transfer genes into high-biomass or crop species for phytoremediation. There is a need to be cautiously optimistic about the application of phytoremediation, taking into account the limits of this strategy. Bringing this technology into common practice is also a challenge. Laboratory conditions using optimal hydroponic growth conditions and exposure to single metals are excellent for understanding physiological processes and the functions of new genes, but they do not represent conditions in the field. Therefore, it is worthwhile to perform phytoremediation tests of transgenic and non-transgenic plants in actual metal-contaminated sites.

\section{REFERENCES}

Adams, J. P., Adeli, A., Hsu, C. Y., Harkess, R. L., Page, G. P., dePamphilis, C. W., Schultz, E. B., and Yuceer, C. 2011. Poplar maintains zinc homeostasis with heavy metal genes HMA4 and PCS1. J Exp Bot 62: 3737-3752.

Agunbiade, F. O., Olu-Owolabi, B. I., and Adebowale, K. O. 2009. Phytoremediation potential of Eichornia crassipes in metal-contaminated coastal water. Bioresource Technol 100: 4521-4526.

Ahmed, G., Miah, M. A., Anawar, H. M., Chowdhury, D. A., and Ahmad, J. U. 2012. Influence of multi-industrial activities on trace metal contamination: an approach towards surface water body in the vicinity of Dhaka Export Processing Zone (DEPZ). Environ Monit Assess 184: 4181-4190.

Alfonso, S. U. and Bruggemann, W. 2012. Photosynthetic responses of a C(3) and three $\mathrm{C}(4)$ species of the genus Panicum (s.l.) with different metabolic subtypes to drought stress. Photosynthesis research 112: 175-191.

Ando, Y., Nagata, S., Yanagisawa, S., and Yoneyama, T. 2013. Copper in xylem and phloem saps from rice (Oryza sativa): the effect of moderate copper concentrations in the growth medium on the accumulation of five essential metals and a speciation analysis of copper-containing compounds. Funct Plant Biol 40: 89-100.

Andreazza, R., Bortolon, L., Pieniz, S., Giacometti, M., Roehrs, D. D., Lambais, M. R., and Camargo, F.A.O. 2011. Potential phytoextraction and phytostabilization of perennial peanut on copper-contaminated vineyard soils and copper mining waste. Biol Trace Elem Res 143: 1729-1739.

Andreazza, R., Okeke, B. C., Lambais, M. R., Bortolon, L., de Melo, G.W.B., and Camargo, F. A. D. 2010. Bacterial stimulation of copper phytoaccumulation by bioaugmentation with rhizosphere bacteria. Chemosphere 81: 1149-1154.

Andres-Colas, N., Perea-Garcia, A., Puig, S., and Penaarubia, L. 2010. Deregulated copper transport affects arabidopsis development especially in the absence of environmental cycles. Plant Physiol 153: 170-184.
Anning, A. K., Korsah, P. E., and Addo-Fordjour, P. 2013. Phytoremediation of wastewater with limnocharis flava, thalia geniculata and typha latifolia in constructed wetlands. Int J Phytoremediat 15: 452-464.

Araki, R., Murata, J., and Murata, Y. 2011. A novel barley yellow stripe 1like transporter (hvysl2) localized to the root endodermis transports metalphytosiderophore complexes. Plant Cell Physiol 52: 1931-1940.

Arrivault, S., Senger, T., and Kramer, U. 2006. The Arabidopsis metal tolerance protein AtMTP3 maintains metal homeostasis by mediating $\mathrm{Zn}$ exclusion from the shoot under Fe deficiency and Zn oversupply. Plant J 46: 861-879.

Arthur, E., Moldrup, P., Holmstrup, M., Schjonning, P., Winding, A., Mayer, P., and de Jonge, L. W. 2012. Soil microbial and physical properties and their relations along a steep copper gradient. Agr Ecosyst Environ 159: 9-18.

Assunção, A. G. L., Herrero, E., Lin, Y. F., Huettel, B., Talukdar, S., Smaczniak, C., Immink, R.G.H., van Eldik, M., Fiers, M., Schat, H., and Aarts, M. G. M. 2010. Arabidopsis thaliana transcription factors bZIP19 and bZIP23 regulate the adaptation to zinc deficiency. P Natl Acad Sci USA 107: 1029610301.

Audet, P. and Charest, C. 2013. Assessing arbuscular mycorrhizal plant metal uptake and soil metal bioavailability among 'dwarf' sunflowers in a stratified compartmental growth environment. Arch Agron Soil Sci 59: 533-548.

Barabasz, A., Mills, R. F., Trojanowska, E., Williams, L. E., and Antosiewicz, D. M. 2011. Expression of AtECA3 in tobacco modifies its responses to manganese, zinc and calcium. Environ Exp Bot 72: 202-209.

Barabasz, A., Wilkowska, A., Ruszczynska, A., Bulska, E., Hanikenne, M., Czarny, M., Kramer, U., and Antosiewicz, D.M. 2012. Metal response of transgenic tomato plants expressing $\mathrm{P}(1 \mathrm{~B})$-ATPase. Physiol Plant 145: 315-331.

Barberon, M., Zelazny, E., Robert, S., Conejero, G., Curie, C., Friml, J., and Vert, G. 2011. Monoubiquitin-dependent endocytosis of the IRON-REGULATED TRANSPORTER 1 (IRT1) transporter controls iron uptake in plants. $P$ Natl Acad Sci USA 108: E450-E458.

Bashir, K., Ishimaru, Y., and Nishizawa, N. K. 2012. Molecular mechanisms of zinc uptake and translocation in rice. Plant Soil 361, 189-201.

Bashir, K., Ishimaru, Y., Shimo, H., Nagasaka, S., Fujimoto, M., Takanashi, H., Tsutsumi, N., An, G., Nakanishi, H., and Nishizawa, N. K. 2011. The rice mitochondrial iron transporter is essential for plant growth. Nat Commun 2.

Behera, S. K., Singh, M. V., Singh, K. N., and Todwal, S. 2011. Distribution variability of total and extractable zinc in cultivated acid soils of India and their relationship with some selected soil properties. Geoderma 162: 242-250.

Bernal, M., Casero, D., Singh, V., Wilson, G. T., Grande, A., Yang, H. J., Dodani, S. C., Pellegrini, M., Huijser, P., Connolly, E. L., Merchant, S. S., and Kramer, U. 2012. Transcriptome sequencing identifies SPL7-regulated copper acquisition genes FRO4/FRO5 and the copper dependence of iron homeostasis in Arabidopsis. Plant Cell 24: 738-761.

Binder, B. M., Rodriguez, F. I., and Bleecker, A. B. 2010. The copper transporter RAN1 is essential for biogenesis of ethylene receptors in Arabidopsis. J Biol Chem 285: 37263-37270.

Bissonnette, L., St-Arnaud, M., and Labrecque, M. 2010. Phytoextraction of heavy metals by two Salicaceae clones in symbiosis with arbuscular mycorrhizal fungi during the second year of a field trial. Plant Soil 332: 55-67.

Boojar, M. M. A., and Tavakkoli, Z. 2011. Antioxidative Responses and Metal Accumulation in Invasive Plant Species Growing on Mine Tailings in Zanjan, Iran. Pedosphere 21: 802-812.

Branzini, A., Gonzalez, R. S., and Zubillaga, M. 2012. Absorption and translocation of copper, zinc and chromium by Sesbania virgata. J Environ Manage 102: $50-54$.

Braud, A., Geoffroy, V., Hoegy, F., Mislin, G. L. A., and Schalk, I. J. 2010. Presence of the siderophores pyoverdine and pyochelin in the extracellular medium reduces toxic metal accumulation in Pseudomonas aeruginosa and increases bacterial metal tolerance. Env Microbiol Rep 2: 419-425.

Bravin, M. N., Garnier, C., Lenoble, V., Gerard, F., Dudal, Y., and Hinsinger, P. 2012. Root-induced changes in $\mathrm{pH}$ and dissolved organic matter binding capacity affect copper dynamic speciation in the rhizosphere. Geochim Cosmochim Ac 84: 256-268. 
Brunetti, G., Farrag, K., Soler-Rovira, P., Ferrara, M., Nigro, F., and Senesi, N. 2012. The effect of compost and Bacillus licheniformis on the phytoextraction of $\mathrm{Cr}, \mathrm{Cu}, \mathrm{Pb}$ and $\mathrm{Zn}$ by three brassicaceae species from contaminated soils in the Apulia region, Southern Italy. Geoderma 170: 322-330.

Buccolieri, A., Buccolieri, G., Dell'Atti, A., Strisciullo, G., and GaglianoCandela, R. 2010. Monitoring of total and bioavailable heavy metals concentration in agricultural soils. Environ Monit Assess 168: 547-560.

Cailliatte, R., Schikora, A., Briat, J. F., Mari, S., and Curie, C. 2010. Highaffinity manganese uptake by the metal transporter nramp1 is essential for Arabidopsis Growth in Low Manganese Conditions. Plant Cell 22: 904-917.

Cambrolle, J., Mancilla-Leyton, J. M., Munoz-Valles, S., Luque, T., and Figueroa, M. E. 2012. Tolerance and accumulation of copper in the saltmarsh shrub Halimione portulacoides. Mar Pollut Bull 64: 721-728.

Canning-Clode, J., Fofonoff, P., Riedel, G. F., Torchin, M., and Ruiz, G. M. 2011. The effects of copper pollution on fouling assemblage diversity: a tropical-temperate comparison. Plos One 6.

Catty, P., Boutigny, S., Miras, R., Joyard, J., Rolland, N., and Seigneurin-Berny, D. 2011. Biochemical characterization of AtHMA6/PAA1, a chloroplast envelope Cu(I)-ATPase. J Biol Chem 286: 36188-36197.

Chandra, R. and Yadav, S. 2011. Phytoremediation of Cd, Cr, Cu, Mn, Fe, $\mathrm{Ni}, \mathrm{Pb}$ and $\mathrm{Zn}$ from aqueous solution using phragmites cummunis, typha angustifolia and cyperus esculentus. Int J Phytoremediat 13: 580-591.

Chehregani, A., Noori, M., and Yazdi, H. L. 2009. Phytoremediation of heavymetal-polluted soils: Screening for new accumulator plants in Angouran mine (Iran) and evaluation of removal ability. Ecotox Environ Safe 72: 1349-1353.

Cheng, W. X. 2009. Rhizosphere priming effect: Its functional relationships with microbial turnover, evapotranspiration, and C-N budgets. Soil Biol Biochem 41: $1795-1801$.

Cheraghi, M., Lorestani, B., and Merrikhpour, H. 2012. Investigation of the effects of phosphate fertilizer application on the heavy metal content in agricultural soils with different cultivation patterns. Biol Trace Elem Res 145: 87-92.

Chigbo, C., Batty, L., and Bartlett, R. 2013. Interactions of copper and pyrene on phytoremediation potential of Brassica juncea in copper-pyrene cocontaminated soil. Chemosphere 90: 2542-2548.

Chipeng, F. K., Hermans, C., Colinet, G., Faucon, M. P., Ngongo, M., Meerts, P., and Verbruggen, N. 2010. Copper tolerance in the cuprophyte Haumaniastrum katangense (S. Moore) PA Duvign. \& Plancke. Plant Soil 328: 235-244.

Chu, H. H., Chiecko, J., Punshon, T., Lanzirotti, A., Lahner, B., Salt, D. E., and Walker, E. L. 2010. Successful reproduction requires the function of Arabidopsis YELLOW STRIPE-LIKE1 and YELLOW STRIPE-LIKE3 metalnicotianamine transporters in both vegetative and reproductive structures. Plant Physiol 154: 197-210.

Colzi, I., Arnetoli, M., Gallo, A., Doumett, S., Del Bubba, M., Pignattelli, S., Gabbrielli, R., and Gonnelli, C. 2012. Copper tolerance strategies involving the root cell wall pectins in Silene paradoxa L. Environ Exp Bot 78: 91-98.

Connorton, J. M., Webster, R. E., Cheng, N. H., and Pittman, J. K. 2012. Knockout of multiple Arabidopsis cation/H+ exchangers suggests isoformspecific roles in metal stress response, germination and seed mineral nutrition. Plos One 7.

Cornejo, P., Pérez-Tienda, J., Meier, S., Valderas, A., Borie, F., Azcón-Aguilar, C., and Ferrol, N. 2013. Copper compartmentalization in spores as a survival strategy of arbuscular mycorrhizal fungi in Cu-polluted environments. Soil Biology and Biochemistry 57: 925-928.

Csavina, J., Field, J., Taylor, M. P., Gao, S., Landazuri, A., Betterton, E. A., and Saez, A. E. 2012. A review on the importance of metals and metalloids in atmospheric dust and aerosol from mining operations. Sci Total Environ 433, $58-73$.

Das, A. P., Sukla, L. B., Pradhan, N., and Nayak, S. 2011. Manganese biomining: A review. Bioresource Technol 102: 7381-7387.

Dasgupta-Schubert, N., Barrera, M. G., Alvarado, C. J., Castillo, O. S., Zaragoza, E. M., Alexander, S., Landsberger, S., and Robinson, S. 2011. The uptake of copper by aldama dentata: Ecophysiological response, its modeling, and the implication for phytoremediation. Water Air Soil Poll 220: 37-55.
Deinlein, U., Weber, M., Schmidt, H., Rensch, S., Trampczynska, A., Hansen, T. H., Husted, S., Schjoerring, J. K., Talke, I. N., Kramer, U., and Clemens, S. 2012. Elevated nicotianamine levels in Arabidopsis halleri roots play a key role in zinc hyperaccumulation. Plant Cell 24: 708-723.

del Pozo, T., Cambiazo, V., and Gonzalez, M. 2010. Gene expression profiling analysis of copper homeostasis in Arabidopsis thaliana. Biochem Bioph Res Co 393: 248-252.

Delhaize, E., Gruber, B. D., Pittman, J. K., White, R. G., Leung, H., Miao, Y. S., Jiang, L. W., Ryan, P. R., and Richardson, A. E. 2007. A role for the AtMTP11 gene of Arabidopsis in manganese transport and tolerance. Plant J 51: 198-210.

Dhillon, K. S., Dhillon, S. K., and Dogra, R. 2010. Selenium accumulation by forage and grain crops and volatilization from seleniferous soils amended with different organic materials. Chemosphere 78: 548-556.

Doganlar, Z. B., and Atmaca, M. 2011. Influence of airborne pollution on Cd, $\mathrm{Zn}, \mathrm{Pb}, \mathrm{Cu}$, and $\mathrm{Al}$ accumulation and physiological parameters of plant leaves in Antakya (Turkey). Water Air Soil Poll 214: 509-523.

Dominguez, M. T., Madrid, F., Maranon, T., and Murillo, J. M. 2009. Cadmium availability in soil and retention in oak roots: Potential for phytostabilization. Chemosphere 76: 480-486.

Donner, E., McLaughlin, M. J., Hodson, M. E., Heemsbergen, D., Warne, M. S., Nortcliff, S., and Broos, K. 2012. Ageing of zinc in highly-weathered iron-rich soils. Plant Soil 361: 83-95.

Dou, C. M., Fu, X. P., Chen, X. C., Shi, J. Y., and Chen, Y. X. 2009. Accumulation and detoxification of manganese in hyperaccumulator Phytolacca americana. Plant Biology 11: 664-670.

Edmond, C., Shigaki, T., Ewert, S., Nelson, M. D., Connorton, J. M., Chalova, V., Noordally, Z., and Pittman, J. K. 2009. Comparative analysis of CAX2like cation transporters indicates functional and regulatory diversity. Biochem J 418: $145-154$

Erenoglu, E. B., Kutman, U. B., Ceylan, Y., Yildiz, B., and Cakmak, I. 2011. Improved nitrogen nutrition enhances root uptake, root-to-shoot translocation and remobilization of zinc (65Zn) in wheat. New Phytol 189: 438-448.

Fukao, Y., Ferjani, A., Tomioka, R., Nagasaki, N., Kurata, R., Nishimori, Y., Fujiwara, M., and Maeshima, M. 2011. iTRAQ analysis reveals mechanisms of growth defects due to excess zinc in Arabidopsis. Plant Physiol 155: 1893-1907.

Gadd, G. M. 2010. Metals, minerals and microbes: geomicrobiology and bioremediation. Microbiol-Sgm 156: 609-643.

Garcia-Molina, A., Andres-Colas, N., Perea-Garcia, A., del Valle-Tascon, S., Penarrubia, L., and Puig, S. 2011. The intracellular Arabidopsis COPT5 transport protein is required for photosynthetic electron transport under severe copper deficiency. Plant J 65: 848-860.

Geissen, V., Ramos, F. Q., Bastidas-Bastidas, P. D., Diaz-Gonzalez, G., BelloMendoza, R., Huerta-Lwanga, E., and Ruiz-Suarez, L. E. 2010. Soil and water pollution in a banana production region in tropical Mexico. $B$ Environ Contam Tox 85: 407-413.

Gerhardt, K. E., Huang, X.-D., Glick, B. R., and Greenberg, B. M. 2009. Phytoremediation and rhizoremediation of organic soil contaminants: Potential and challenges. Plant Science 176: 20-30.

Ghiri, M. N., Rezaei, M., and Sameni, A. 2012. Zinc sorption-desorption by sand, silt and clay fractions in calcareous soils of Iran. Arch Agron Soil Sci 58: $945-957$.

Godfray, H.C.J., Beddington, J. R., Crute, I. R., Haddad, L., Lawrence, D., Muir, J. F., Pretty, J., Robinson, S., Thomas, S. M. and Toulmin, C. 2010. Food security: The challenge of feeding 9 billion people. Science 327: 812-818.

Gonzalez-Fernandez, O., Queralt, I., Carvalho, M. L., and Garcia, G. 2011. Lead, zinc, arsenic and copper pollution in the alluvial plain of a mining wadi: The Beal case (Cartagena-La Union Mining District, SE Spain). Water Air Soil Poll 220: 279-291.

Grebe, M. 2011. PLANT BIOLOGY Unveiling the Casparian strip. Nature 473: 294-295.

Gunawardana, B., Singhal, N., and Johnson, A. 2011. Effects of amendments on copper, cadmium, and lead phytoextraction by lolium perenne 
from multiple-metal contaminated solution. Int J Phytoremediat 13: 215232.

Guo, J. B., Xu, W. Z., and Ma, M. 2012. The assembly of metals chelation by thiols and vacuolar compartmentalization conferred increased tolerance to and accumulation of cadmium and arsenic in transgenic Arabidopsis thaliana. J Hazard Mater 199: 309-313.

Gustin, J. L., Zanis, M. J., and Salt, D. E. 2011. Structure and evolution of the plant cation diffusion facilitator family of ion transporters. Bmc Evol Biol 11.

Ha, N.T.H., Sakakibara, M., and Sano, S. 2009. Phytoremediation of Sb, As, $\mathrm{Cu}$, and $\mathrm{Zn}$ from contaminated water by the aquatic macrophyte eleocharis acicularis. Clean-Soil Air Water 37: 720-725.

Hajiboland, R. and Amirazad, F. (2010) Growth, photosynthesis and antioxidant defense system in Zn-deficient red cabbage plants. Plant Soil Environ 56: 209-217.

Hansch, R. and Mendel, R. R. 2009. Physiological functions of mineral micronutrients $(\mathrm{Cu}, \mathrm{Zn}, \mathrm{Mn}, \mathrm{Fe}, \mathrm{Ni}, \mathrm{Mo}, \mathrm{B}, \mathrm{Cl})$. Curr Opin Plant Biol 12: 259-266.

Harris, W. R., Sammons, R. D., and Grabiak, R. C. 2012. A speciation model of essential trace metal ions in phloem. J Inorg Biochem 116: 140-150.

Haydon, M. J., Kawachi, M., Wirtz, M., Hillmer, S., Hell, R., and Kramer, U. 2012. Vacuolar nicotianamine has critical and distinct roles under iron deficiency and for zinc sequestration in Arabidopsis. Plant Cell 24: 724 737.

Heredia, O. S. and Cirelli, A. F. 2009. Trace elements distribution in soil, pore water and groundwater in Buenos Aires, Argentina. Geoderma 149: 409-414.

Hernandez-Ortega, H. A., Alarcon, A., Ferrera-Cerrato, R., Zavaleta-Mancera, H. A., Lopez-Delgado, H. A., and Mendoza-Lopez, M. R. 2012. Arbuscular mycorrhizal fungi on growth, nutrient status, and total antioxidant activity of Melilotus albus during phytoremediation of a diesel-contaminated substrate. J Environ Manage 95, S319-S324.

Hinojosa, M. B., Carreira, J. A., Garcia-Ruiz, R., Rodriguez-Maroto, J. M., Daniell, T. J., and Griffiths, B. S. 2010. Plant treatment, pollutant load, and soil type effects in rhizosphere ecology of trace element polluted soils. Ecotox Environ Safe 73: 970-981.

Hu, N., Zheng, J. F., Ding, D. X., Liu, J., Yang, L. Q., Yin, J., Li, G. Y., Wang, Y. D., and Liu, Y. L. 2009. Metal pollution in Huayuan River in Hunan Province in China by manganese sulphate waste residue. B Environ Contam Tox 83: 583-590.

Hu, Y. T., Ming, F., Chen, W. W., Yan, J. Y., Xu, Z. Y., Li, G. X., Xu, C. Y., Yang, J. L., and Zheng, S. J. 2012. TcOPT3, a member of oligopeptide transporters from the hyperaccumulator Thlaspi caerulescens, is a novel $\mathrm{Fe} / \mathrm{Zn} / \mathrm{Cd} / \mathrm{Cu}$ transporter. Plos One 7, e38535.

Hua, J. F., Zhang, C. S., Yin, Y. L., Chen, R. R., and Wang, X. X. 2012. Phytoremediation potential of three aquatic macrophytes in manganese-contaminated water. Water and Environment Journal 26: 335-342.

Husson, O. 2013. Redox potential (Eh) and $\mathrm{pH}$ as drivers of soil/plant/microorganism systems: a transdisciplinary overview pointing to integrative opportunities for agronomy. Plant Soil 362: 389-417.

Irtelli, B., Petrucci, W. A., and Navari-Izzo, F. 2009. Nicotianamine and histidine/proline are, respectively, the most important copper chelators in xylem sap of Brassica carinata under conditions of copper deficiency and excess. $J$ Exp Bot 60: 269-277.

Ishimaru, Y., Masuda, H., Bashir, K., Inoue, H., Tsukamoto, T., Takahashi, M., Nakanishi, H., Aoki, N., Hirose, T., Ohsugi, R., and Nishizawa, N. K. 2010. Rice metal-nicotianamine transporter, OsYSL2, is required for the long-distance transport of iron and manganese. Plant J 62: 379-390.

Ishimaru, Y., Takahashi, R., Bashir, K., Shimo, H., Senoura, T., Sugimoto, K., Ono, K., Yano, M., Ishikawa, S., Arao, T., Nakanishi, H., and Nishizawa, N.K. 2012. Characterizing the role of rice NRAMP5 in manganese, iron and cadmium transport. Sci Rep-Uk $\mathbf{2}$.

Jalali, M. and Zinli, N.A.M. 2012. Effects of common ions on Zn Sorption in some calcareous soils of western Iran. Pedosphere 22: 190-200.

Jeong, J. and Connolly, E.L. 2009. Iron uptake mechanisms in plants: Functions of the FRO family of ferric reductases. Plant Science 176: 709-714.
Joly, A., Lambert, J., Gagnon, C., Kennedy, G., Mergler, D., Adam-Poupart, A., and Zayed, J. 2011. Reduced atmospheric manganese in Montreal following removal of methylcyclopentadienyl manganese tricarbonyl (MMT). Water, Air, \& Soil Pollution 219: 263-270.

Juarez-Santillan, L. F., Lucho-Constantino, C. A., Vazquez-Rodriguez, G. A., Ceron-Ubilla, N. M., and Beltran-Hernandez, R. I. 2010. Manganese accumulation in plants of the mining zone of Hidalgo, Mexico. Bioresource Technol 101: $5836-5841$.

Jung, H. I., Gayomba, S. R., Rutzke, M. A., Craft, E., Kochian, L. V., and Vatamaniuk, O. K. 2012. COPT6 is a plasma membrane transporter that functions in copper homeostasis in Arabidopsis and is a novel target of SQUAMOSA promoter-binding protein-like 7. J Biol Chem 287: 33252-33267.

Kasmaei, L.S. and Fekri, M. 2012. Effect of organic matter on the release behavior and extractability of copper and cadmium in soil. Commun Soil Sci Plan 43, 2209-2217.

Kato, M., Ishikawa, S., Inagaki, K., Chiba, K., Hayashi, H., Yanagisawa, S., and Yoneyama, T. 2010. Possible chemical forms of cadmium and varietal differences in cadmium concentrations in the phloem sap of rice plants (Oryza sativa L.). Soil Sci Plant Nutr 56: 839-847.

Kawachi, M., Kobae, Y., Mori, H., Tomioka, R., Lee, Y., and Maeshima, M. 2009. A mutant strain Arabidopsis thaliana that lacks vacuolar membrane zinc transporter MTP1 revealed the latent tolerance to excessive zinc. Plant Cell Physiol 50: 1156-1170.

Kim, K. R. and Owens, G. 2009. Chemodynamics of heavy metals in long-term contaminated soils: Metal speciation in soil solution. J Environ Sci-China 21: 1532-1540.

Kim, K. R., Owens, G., Naidu, R., and Kwon, S. I. 2010. Influence of plant roots on rhizosphere soil solution composition of long-term contaminated soils. Geoderma 155: 86-92.

Kim, Y. O., Jung, S., Kim, K., and Bae, H. J. 2013. Role of pCeMT, a putative metallothionein from Colocasia esculenta, in response to metal stress. Plant Physiology and Biochemistry : PPB / Societe francaise de physiologie vegetale 64: $25-32$.

Kim, Y. Y., Choi, H., Segami, S., Cho, H. T., Martinoia, E., Maeshima, M., and Lee, Y. 2009. AtHMA1 contributes to the detoxification of excess $\mathrm{Zn}$ (II) in Arabidopsis. Plant J 58: 737-753.

Klaumann, S., Nickolaus, S. D., Furst, S. H., Starck, S., Schneider, S., Neuhaus, H. E., and Trentmann, O. 2011. The tonoplast copper transporter COPT5 acts as an exporter and is required for interorgan allocation of copper in Arabidopsis thaliana. New Phytol 192: 393-404.

Kobayashi, Y., Kuroda, K., Kimura, K., Southron-Francis, J. L., Furuzawa, A., Kimura, K., Iuchi, S., Kobayashi, M., Taylor, G. J., and Koyama, H. 2008. Amino acid polymorphisms in strictly conserved domains of a P-type ATPase HMA5 are involved in the mechanism of copper tolerance variation in Arabidopsis. Plant Physiol 148: 969-980.

Komarek, M., Szakova, J., Rohoskova, M., Javorska, H., Chrastny, V., and Balik, J. (2008) Copper contamination of vineyard soils from small wine producers: A case study from the Czech Republic. Geoderma 147: 16-22.

Korenkov, V., Hirschi, K., Crutchfield, J. D., and Wagner, G. J. (2007) Enhancing tonoplast $\mathrm{Cd} / \mathrm{H}$ antiport activity increases $\mathrm{Cd}, \mathrm{Zn}$, and Mn tolerance, and impacts root/shoot Cd partitioning in Nicotiana tabacum L. Planta 226: 1379-1387.

Kramer, U. 2010. Metal hyperaccumulation in plants. Annи Rev Plant Biol 61: 517-534.

Kumari, B. and Singh, S. N. 2011. Phytoremediation of metals from fly ash through bacterial augmentation. Ecotoxicology 20: 166-176.

Kumpiene, J., Guerri, G., Landi, L., Pietramellara, G., Nannipieri, P., and Renella, G. 2009. Microbial biomass, respiration and enzyme activities after in situ aided phytostabilization of a $\mathrm{Pb}$ - and $\mathrm{Cu}$-contaminated soil. Ecotox Environ Safe 72: 115-119.

Kupper, H., Gotz, B., Mijovilovich, A., Kupper, F. C., and Meyer-Klaucke, W. 2009. Complexation and toxicity of copper in higher plants. I. Characterization of copper accumulation, speciation, and toxicity in crassula helmsii as a new copper accumulator. Plant Physiol 151: 702-714. 
Lanquar, V., Ramos, M. S., Lelievre, F., Barbier-Brygoo, H., Krieger-Liszkay, A., Kramer, U., and Thomine, S. 2010. Export of vacuolar manganese by AtNRAMP3 and AtNRAMP4 is required for optimal photosynthesis and growth under manganese deficiency. Plant Physiol 152: 1986-1999.

Larbi, A., Morales, F., Abadia, A., and Abadia, J. 2010. Changes in iron and organic acid concentrations in xylem sap and apoplastic fluid of irondeficient Beta vulgaris plants in response to iron resupply. J Plant Physiol 167: $255-260$.

Lee, S. and An, G. 2009. Over-expression of OsIRT1 leads to increased iron and zinc accumulations in rice. Plant Cell Environ 32: 408-416.

Lee, S., Jeong, H. J., Kim, S. A., Lee, J., Guerinot, M. L., and An, G. 2010a. OsZIP5 is a plasma membrane zinc transporter in rice. Plant Mol Biol 73: 507-517.

Lee, S., Kim, S. A., Lee, J., Guerinot, M. L., and An, G. 2010b. Zinc deficiencyinducible OsZIP8 encodes a plasma membrane-localized zinc transporter in rice. Mol Cells 29: 551-558.

Lee, S., Persson, D. P., Hansen, T. H., Husted, S., Schjoerring, J. K., Kim, Y. S., Jeon, U. S., Kim, Y. K., Kakei, Y., Masuda, H., Nishizawa, N. K., and An, G. 2011. Bio-available zinc in rice seeds is increased by activation tagging of nicotianamine synthase. Plant Biotechnol J 9: 865-873.

Lee, S., Ryoo, N., Jeon, J. S., Guerinot, M. L., and An, G. 2012. Activation of rice yellow stripe1-like 16 (OsYSL16) enhances iron efficiency. Mol Cells 33: $117-126$.

Leitenmaier, B. and Kupper, H. 2011. Cadmium uptake and sequestration kinetics in individual leaf cell protoplasts of the $\mathrm{Cd} / \mathrm{Zn}$ hyperaccumulator Thlaspi caerulescens. Plant Cell Environ 34: 208-219.

Li, T. Q., Di, Z. Z., Islam, E., Jiang, H., and Yang, X. E. 2011. Rhizosphere characteristics of zinc hyperaccumulator Sedum alfredii involved in zinc accumulation. J Hazard Mater 185: 818-823.

Li, X., Chanroj, S., Wu, Z., Romanowsky, S. M., Harper, J. F., and Sze, H. 2008. A distinct endosomal $\mathrm{Ca} 2+/ \mathrm{Mn} 2+$ pump affects root growth through the secretory process. Plant Physiol 147: 1675-1689.

Lin, Y. F., Liang, H. M., Yang, S.Y., Boch, A., Clemens, S., Chen, C. C., Wu, J. F., Huang, J. L., and Yeh, K. C. 2009. Arabidopsis IRT3 is a zinc-regulated and plasma membrane localized zinc/iron transporter. New Phytol 182: 392 404.

Liu, J. G., Li, G. H., Shao, W. C., Xu, J. K., and Wang, D. K. 2010a. Variations in uptake and translocation of copper, chromium and nickel among nineteen wetland plant species. Pedosphere 20, 96-103.

Liu, P., Tang, X.M., Gong, C. F., and Xu, G. D. 2010b. Manganese tolerance and accumulation in six Mn hyperaccumulators or accumulators. Plant Soil 335: 385-395.

Lu, Q., He, Z.L.L., Graetz, D. A., Stoffella, P. J., and Yang, X. E. 2011. Uptake and distribution of metals by water lettuce (Pistia stratiotes L.). Environ Sci Pollut Res 18: 978-986.

Luo, X. S., Yu, S., and Li, X. D. 2011. Distribution, availability, and sources of trace metals in different particle size fractions of urban soils in Hong Kong: Implications for assessing the risk to human health. Environ Pollut 159: $1317-1326$.

Luo, X. S., Yu, S., Zhu, Y. G., and Li, X. D. 2012. Trace metal contamination in urban soils of China. Sci Total Environ 421, 17-30.

Machado-Estrada, B., Calderón, J., Moreno-Sánchez, R., and Rodríguez-Zavala, J. 2012. Accumulation of arsenic, lead, copper, and zinc, and synthesis of phytochelatins by indigenous plants of a mining impacted area. Environ Sci Pollut Res, 1-10.

Mackie, K. A., Muller, T., and Kandeler, E. 2012. Remediation of copper in vineyards - A mini review. Environ Pollut 167, 16-26.

Manh, P. N., Khan, M. A., Jeon, B. H., Kim, J. G., and Lee, G. 2011. Stability of Fe- and Mn-(oxyhydr)oxides in common soil dispersion solutions. Water Air Soil Poll 217: 677-687.

Masuda, H., Usuda, K., Kobayashi, T., Ishimaru, Y., Kakei, Y., Takahashi, M., Higuchi, K., Nakanishi, H., Mori, S., and Nishizawa, N. K. 2009. Overexpression of the barley nicotianamine synthase gene HvNAS1 Increases iron and zinc concentrations in rice grains. Rice 2: 155-166.
McArthur, J. M., Sikdar, P. K., Nath, B., Grassineau, N., Marshall, J. D., and Banerjee, D. M. 2012. Sedimentological control on Mn, and other trace elements, in groundwater of the Bengal Delta. Environ Sci Technol 46: 669-676.

Meier, S., Borie, F., Bolan, N., and Cornejo, P. 2012. Phytoremediation of metal-polluted soils by arbuscular mycorrhizal fungi. Crit Rev Env Sci Tec 42: 741-775.

Melo, A., Pinto, E., Aguiar, A., Mansilha, C., Pinho, O., and Ferreira, I.M.P.L.V.O. 2012. Impact of intensive horticulture practices on groundwater content of nitrates, sodium, potassium, and pesticides. Environ Monit Assess 184: 4539-4551.

Merdy, P., Gharbi, L. T., and Lucas, Y. 2009. Pb, Cu and $\mathrm{Cr}$ interactions with soil: Sorption experiments and modelling. Colloid Surface A 347: 192-199.

Miguel, B., Edell, A., Edson, Y., and Edwin, P. 2013. A phytoremediation approach using Calamagrostis ligulata and Juncus imbricatus in Andean wetlands of Peru. Environ Monit Assess 185: 323-334.

Mikkelsen, M. D., Pedas, P., Schiller, M., Vincze, E., Mills, R. F., Borg, S., Moller, A., Schjoerring, J. K., Williams, L. E., Baekgaard, L., Holm, P. B., and Palmgren, M. G. 2012. Barley HvHMA1 is a heavy metal pump involved in mobilizing organellar $\mathrm{Zn}$ and $\mathrm{Cu}$ and plays a role in metal loading into grains. Plos One 7.

Mikutta, R., Baumgaertner, A., Schippers, A., Haumaier, L., and Guggenberger, G. 2012. Extracellular polymeric substances from Bacillus subtilis associated with minerals modify the extent and rate of heavy metal sorption. Environ Sci Technol 46: 3866-3873.

Millaleo, R., Reyes-Diaz, M., Alberdi, M., Ivanov, A. G., Krol, M., and Huner, N.P.A. 2013. Excess manganese differentially inhibits photosystem I versus II in Arabidopsis thaliana. J Exp Bot 64: 343-354.

Mills, R. F., Doherty, M .L., Lopez-Marques, R. L., Weimar, T., Dupree, P., Palmgren, M. G., Pittman, J. K., and Williams, L. E. (2008) ECA3, a Golgilocalized P-2A-type ATPase, plays a crucial role in manganese nutrition in Arabidopsis. Plant Physiol 146: 116-128.

Mills, R. F., Peaston, K. A., Runions, J., and Williams, L. E. 2012. HvHMA2, a P-1B-ATPase from barley, is highly conserved among cereals and functions in $\mathrm{Zn}$ and $\mathrm{Cd}$ transport. Plos One 7.

Milner, M. J., Seamon, J., Craft, E., and Kochian, L. V. 2013. Transport properties of members of the ZIP family in plants and their role in $\mathrm{Zn}$ and $\mathrm{Mn}$ homeostasis. J Exp Bot 64: 369-381.

Mishra, V. K., and Tripathi, B. D. 2009. Accumulation of chromium and zinc from aqueous solutions using water hyacinth (Eichhornia crassiples). $\mathrm{J} \mathrm{Haz}$ ard Mater 164: 1059-1063.

Morandi, B., Losciale, P., Manfrini, L., Pierpaoli, E., Zibordi, M., and Grappadelli, L. C. 2012. Short-period changes in weather conditions affect xylem, but not phloem flows to young kiwifruit (Actinidia deliciosa) berries. Sci Hortic-Amsterdam 142, 74-83.

Morel, M., Crouzet, J., Gravot, A., Auroy, P., Leonhardt, N., Vavasseur, A., and Richaud, P. 2009. AtHMA3, a P-1B-ATPase allowing $\mathrm{Cd} / \mathrm{Zn} / \mathrm{Co} / \mathrm{Pb}$ vacuolar storage in Arabidopsis. Plant Physiol 149: 894-904.

Mrnka, L., Kuchar, M., Cieslarova, Z., Matejka, P., Szakova, J., Tlustos, P., and Vosatka, M. 2012. Effects of endo- and ectomycorrhizal fungi on physiological parameters and heavy metals accumulation of two species from the family Salicaceae. Water Air Soil Poll 223: 399-410.

Mundus, S., Lombi, E., Holm, P. E., Zhang, H., and Husted, S. 2012. Assessing the plant availability of manganese in soils using diffusive gradients in thin films (DGT). Geoderma 183: 92-99.

Murakami, M. and Ae, N. 2009. Potential for phytoextraction of copper, lead, and zinc by rice (Oryza sativa L.), soybean (Glycine max [L.] Merr.), and maize (Zea mays L.). J Hazard Mater 162: 11851192.

Murata, Y., Harada, E., Sugase, K., Namba, K., Horikawa, M., Ma, J. F., Yamaji, N., Ueno, D., Nomoto, K., Iwashita, T., and Kusumoto, S. 2008. Specific transporter for iron(III)-phytosiderophore complex involved in iron uptake by barley roots. Pure Appl Chem 80: 2689-2697.

Najeeb, U., Xu, L., Ali, S., Jilani, G., Gong, H. J., Shen, W. Q., and Zhou, W. J. 2009. Citric acid enhances the phytoextraction of manganese and plant growth 
by alleviating the ultrastructural damages in Juncus effusus L. J Hazard Mater 170: $1156-1163$.

Ning, D., Wang, F., Zhou, C. B., Zhu, C. L., and Yu, H. B. 2010. Analysis of pollution materials generated from electrolytic manganese industries in China. Resour Conserv Recy 54: 506-511.

Nishiyama, R., Kato, M., Nagata, S., Yanagisawa, S., and Yoneyama, T. 2012. Identification of Zn-Nicotianamine and Fe-2'-Deoxymugineic acid in the phloem sap from rice plants (Oryza sativa L.). Plant Cell Physiol 53: 381-390.

Orsini, F., Alnayef, M., Bona, S., Maggio, A., and Gianquinto, G. 2012. Low stomatal density and reduced transpiration facilitate strawberry adaptation to salinity. Environ Exp Bot 81, 1-10.

Padmavathiamma, P. K. and Li, L. Y. 2010. Phytoavailability and fractionation of lead and manganese in a contaminated soil after application of three amendments. Bioresource Technol 101: 5667-5676.

Palmer, C. M. and Guerinot, M. L. 2009. Facing the challenges of $\mathrm{Cu}, \mathrm{Fe}$ and Zn homeostasis in plants. Nat Chem Biol 5: 333-340.

Pandey, V. C. 2012. Phytoremediation of heavy metals from fly ash pond by Azolla caroliniana. Ecotox Environ Safe 82, 8-12.

Panz, K. and Miksch, K. 2012. Phytoremediation of explosives (TNT, RDX, HMX) by wild-type and transgenic plants. J Environ Manage 113: 85-92.

Pedas, P., Ytting, C. K., Fuglsang, A. T., Jahn, T. P., Schjoerring, J. K., and Husted, S. 2008. Manganese efficiency in barley: Identification and characterization of the metal ion transporter HvIRT1. Plant Physiol 148: 455-466.

Perez-Esteban, J., Escolastico, C., Moliner, A., and Masaguer, A. 2013. Chemical speciation and mobilization of copper and zinc in naturally contaminated mine soils with citric and tartaric acids. Chemosphere 90: 276-283.

Phalan, B., Balmford, A., Green, R. E., and Scharlemann, J.P.W. 2011. Minimising the harm to biodiversity of producing more food globally. Food Policy 36: S62-S71.

Pignattelli, S., Colzi, I., Buccianti, A., Cecchi, L., Arnetoli, M., Monnanni, R., Gabbrielli, R., and Gonnelli, C. 2012. Exploring element accumulation patterns of a metal excluder plant naturally colonizing a highly contaminated soil. J Hazard Mater 227: 362-369.

Pilon, M., Cohu, C. M., Ravet, K., Abdel-Ghany, S. E., and Gaymard, F. 2009. Essential transition metal homeostasis in plants. Curr Opin Plant Biol 12: 347-357.

Pineau, C., Loubet, S., Lefoulon, C., Chalies, C., Fizames, C., Lacombe, B., Ferrand, M., Loudet, O., Berthomieu, P., and Richard, O. 2012. Natural variation at the FRD3 MATE transporter locus reveals cross-talk between $\mathrm{Fe}$ homeostasis and $\mathrm{Zn}$ tolerance in Arabidopsis thaliana. Plos Genet $\mathbf{8}$.

Pinto, E., Petisca, C., Amaro, L. F., Pinho, O., and Ferreira, I. M. P. L. V. O. 2010. Influence of different extraction conditions and sample pretreatments on quantification of nitrate and nitrite in spinach and lettuce. J Liq Chromatogr $R T$ 33: 591-602.

Podar, D., Scherer, J., Noordally, Z., Herzyk, P., Nies, D., and Sanders, D. 2012. Metal selectivity determinants in a family of transition metal transporters. $J$ Biol Chem 287: 3185-3196.

Powlson, D. S., Gregory, P. J., Whalley, W. R., Quinton, J. N., Hopkins, D. W., Whitmore, A. P., Hirsch, P. R., and Goulding, K. W. T. 2011. Soil management in relation to sustainable agriculture and ecosystem services. Food Policy $\mathbf{3 6}$, S72-S87.

Ptashnyk, M., Roose, T., Jones, D. L., and Kirk, G. J. D. 2011. Enhanced zinc uptake by rice through phytosiderophore secretion: a modelling study. Plant Cell Environ 34: 2038-2046.

Puig, S. and Penarrubia, L. 2009. Placing metal micronutrients in context: transport and distribution in plants. Curr Opin Plant Biol 12: 299-306.

Puschenreiter, M., Wittstock, F., Friesl-Hanl, W., and Wenzel, W. 2013. Predictability of the $\mathrm{Zn}$ and Cd phytoextraction efficiency of a Salix smithiana clone by DGT and conventional bioavailability assays. Plant Soil, 1-11.

Quinton, J. N., Govers, G., Van Oost, K., and Bardgett, R. D. 2010. The impact of agricultural soil erosion on biogeochemical cycling. Nat Geosci 3: 311-314.

Rajapaksha, A. U., Vithanage, M., Oze, C., Bandara, W. M. A. T., and Weerasooriya, R. 2012. Nickel and manganese release in serpentine soil from the Ussangoda Ultramafic Complex, Sri Lanka. Geoderma 189: 1-9.
Rajkumar, M., Sandhya, S., Prasad, M. N. V., and Freitas, H. 2012. Perspectives of plant-associated microbes in heavy metal phytoremediation. Biotechnol Adv 30: 1562-1574.

Ramegowda, Y., Venkategowda, R., Jagadish, P., Govind, G., Hanumanthareddy, R.-R., Makarla, U., and Guligowda, S. 2012. Expression of a rice Zn transporter, OsZIP1, increases Zn concentration in tobacco and finger millet transgenic plants. Plant Biotechnol Rep, 1-11.

Ravet, K., Danford, F. L., Dihle, A., Pittarello, M., and Pilon, M. 2011. Spatiotemporal analysis of copper homeostasis in Populus trichocarpa reveals an integrated molecular remodeling for a preferential allocation of copper to plastocyanin in the chloroplasts of developing leaves. Plant Physiol 157: 1300-1312.

Rellan-Alvarez, R., Abadia, J., and Alvarez-Fernandez, A. 2008. Formation of metal-nicotianamine complexes as affected by $\mathrm{pH}$, ligand exchange with citrate and metal exchange. A study by electrospray ionization time-of-flight mass spectrometry. Rapid Commun Mass Sp 22: 1553-1562.

Saebo, A., Popek, R., Nawrot, B., Hanslin, H. M., Gawronska, H., and Gawronski, S. W. 2012. Plant species differences in particulate matter accumulation on leaf surfaces. Sci Total Environ 427: 347-354.

Sakakibara, M., Ohmori, Y., Nguyen, T. H. H., Sano, S., and Sera, K. 2011. Phytoremediation of heavy metal-contaminated water and sediment by Eleocharis acicularis. Clean-Soil Air Water 39: 735-741.

Salt, D. E., Baxter, I., and Lahner, B. 2008. Ionomics and the study of the plant ionome. Annual Review of Plant Biology 59: 709-733.

Sanchez-Pardo, B., Fernandez-Pascual, M., and Zornoza, P. 2012. Copper microlocalisation, ultrastructural alterations and antioxidant responses in the nodules of white lupin and soybean plants grown under conditions of copper excess. Environ Exp Bot 84: 52-60.

Santos-Diaz, M. D. and Barron-Cruz, M. D. 2011. Lead, chromium and manganese removal by in vitro root cultures of two aquatic macrophytes species: Typha Latifolia L. And Scirpus Americanus Pers. Int J Phytoremediat 13: 538-551.

Sasaki, A., Yamaji, N., Xia, J. X., and Ma, J. F. 2011. OsYSL6 is involved in the detoxification of excess manganese in rice. Plant Physiol 157: 1832-1840.

Sasmaz, A., Obek, E., and Hasar, H. 2008. The accumulation of heavy metals in Typha latifolia L. grown in a stream carrying secondary effluent. Ecol Eng 33: $278-284$.

Schalk, I. J., Hannauer, M., and Braud, A. 2011. New roles for bacterial siderophores in metal transport and tolerance. Environ Microbiol 13: 2844-2854.

Schmidt, M. A., Gonzalez, J. M., Halvorson, J. J., and Hagerman, A. E. 2013. Metal mobilization in soil by two structurally defined polyphenols. Chemosphere 90: 1870-1877.

Schreck, E., Foucault, Y., Sarret, G., Sobanska, S., Cecillon, L., Castrec-Rouelle, M., Uzu, G., and Dumat, C. 2012. Metal and metalloid foliar uptake by various plant species exposed to atmospheric industrial fallout: Mechanisms involved for lead. Sci Total Environ 427: 253-262.

Schwarzenbach, R. P., Egli, T., Hofstetter, T. B., von Gunten, U., and Wehrli, B. 2010. Global water pollution and human health. Annual Review of Environment and Resources, Vol 35 35: 109-136.

Sekhar, K., Priyanka, B., Reddy, V. D., and Rao, K. V. 2011. Metallothionein 1 (CcMT1) of pigeonpea (Cajanus cajan, L.) confers enhanced tolerance to copper and cadmium in Escherichia coli and Arabidopsis thaliana. Environ Exp Bot 72: 131-139.

Shanmugam, V., Lo, J. C., Wu, C. L., Wang, S. L., Lai, C. C., Connolly, E. L., Huang, J. L., and Yeh, K. C. 2011. Differential expression and regulation of iron-regulated metal transporters in Arabidopsis halleri and Arabidopsis thaliana - the role in zinc tolerance. New Phytol 190: 125-137.

Shi, J. Y., Lin, H. R., Yuan, X. F., Chen, X. C., Shen, C. F., and Chen, Y. X. 2011. Enhancement of copper availability and microbial community changes in rice rhizospheres affected by sulfur. Molecules 16: 1409-1417.

Shim, D., Kim, S., Choi, Y. I., Song, W. Y., Park, J., Youk, E. S., Jeong, S. C., Martinoia, E., Noh, E. W., and Lee, Y. 2013. Transgenic poplar trees expressing yeast cadmium factor 1 exhibit the characteristics 
necessary for the phytoremediation of mine tailing soil. Chemosphere 90: $1478-1486$.

Shukla, O. P., Juwarkar, A. A., Singh, S. K., Khan, S., and Rai, U. N. 2011. Growth responses and metal accumulation capabilities of woody plants during the phytoremediation of tannery sludge. Waste Manage 31: 115-123.

Siemianowski, O., Mills, R. F., Williams, L. E., and Antosiewicz, D. M. 2011. Expression of the P-1B-type ATPase AtHMA4 in tobacco modifies $\mathrm{Zn}$ and Cd root to shoot partitioning and metal tolerance. Plant Biotechnol J 9: 64-74.

Sirguey, C. and Ouvrard, S. 2013. Contaminated soils salinity, a threat for phytoextraction? Chemosphere 91: 269-274.

Slater, H., Gouin, T., and Leigh, M. B. 2011. Assessing the potential for rhizoremediation of PCB contaminated soils in northern regions using native tree species. Chemosphere 84: 199-206.

Song, W. Y., Choi, K. S., Kim, D. Y., Geisler, M., Park, J., Vincenzetti, V., Schellenberg, M., Kim, S. H., Lim, Y. P., Noh, E. W., Lee, Y., and Martinoia, E. 2010. Arabidopsis PCR2 is a zinc exporter involved in both zinc extrusion and long-distance zinc transport. Plant Cell 22: 2237-2252.

Stacey, M. G., Patel, A., McClain, W. E., Mathieu, M., Remley, M., Rogers, E. E., Gassmann, W., Blevins, D. G., and Stacey, G. 2008. The Arabidopsis AtOPT3 protein functions in metal homeostasis and movement of iron to developing seeds. Plant Physiol 146: 589-601.

Stephan, C. H., Courchesne, F., Hendershot, W. H., McGrath, S. P., Chaudri, A. M., Sappin-Didier, V., and Sauve, S. 2008. Speciation of zinc in contaminated soils. Environ Pollut 155: 208-216.

Stephens, B. W., Cook, D. R., and Grusak, M. A. 2011. Characterization of zinc transport by divalent metal transporters of the ZIP family from the model legume Medicago truncatula. Biometals 24: 51-58.

Stern, B. R. 2010. Essentiality and toxicity in copper health risk assessment: Overview, update and regulatory considerations. J Toxicol Env Heal A 73: 114-127.

Suzuki, M., Tsukamoto, T., Inoue, H., Watanabe, S., Matsuhashi, S., Takahashi, M., Nakanishi, H., Mori, S., and Nishizawa, N. K. 2008. Deoxymugineic acid increases $\mathrm{Zn}$ translocation in $\mathrm{Zn}$-deficient rice plants. Plant Mol Biol 66: 609-617.

Takahashi, R., Ishimaru, Y., Shimo, H., Ogo, Y., Senoura, T., Nishizawa, N. K., and Nakanishi, H. 2012. The OsHMA2 transporter is involved in root-to-shoot translocation of $\mathrm{Zn}$ and $\mathrm{Cd}$ in rice. Plant Cell Environ 35: 1948-1957.

Tan, J., Wang, J., Chai, T., Zhang, Y., Feng, S., Li, Y., Zhao, H., Liu, H., and Chai, X. 2013. Functional analyses of TaHMA2, a P(1B) -type ATPase in wheat. Plant Biotechnol J.

Tang, Y. T., Qiu, R.L., Zeng, X. W., Ying, R. R., Yu, F. M., and Zhou, X. Y. 2009. Lead, zinc, cadmium hyperaccumulation and growth stimulation in Arabis paniculata Franch. Environ Exp Bot 66: 126-134.

Tapken, W., Ravet, K., and Pilon, M. 2012. Plastocyanin controls the stabilization of the thylakoid Cu-transporting P-type ATPase PAA2/HMA8 in response to low copper in Arabidopsis. J Biol Chem 287: 18544-18550.

Techer, D., Laval-Gilly, P., Henry, S., Bennasroune, A., Formanek, P., MartinezChois, C., D’Innocenzo, M., Muanda, F., Dicko, A., Rejsek, K., and Falla, J. 2011. Contribution of Miscanthus x giganteus root exudates to the biostimulation of PAH degradation: An in vitro study. Sci Total Environ 409: 4489-4495.

Testiati, E., Parinet, J., Massiani, C., Laffont-Schwob, I., Rabier, J., Pfeifer, H. R., Lenoble, V., Masotti, V., and Prudent, P. 2013. Trace metal and metalloid contamination levels in soils and in two native plant species of a former industrial site: Evaluation of the phytostabilization potential. $J$ Hazard Mater 248-249C: 131-141.

Turchi, A., Tamantini, I., Camussi, A. M., and Racchi, M. L. 2012. Expression of a metallothionein A1 gene of Pisum sativum in white poplar enhances tolerance and accumulation of zinc and copper. Plant Science 183: 50-56.

Uraguchi, S., Kiyono, M., Sakamoto, T., Watanabe, I., and Kuno, K. 2009. Contributions of apoplasmic cadmium accumulation, antioxidative enzymes and induction of phytochelatins in cadmium tolerance of the cadmiumaccumulating cultivar of black oat (Avena strigosa Schreb.). Planta 230: 267-276.
Valderrama, A., Tapia, J., Peñailillo, P., and Carvajal, D. E. 2012. Water phytoremediation of cadmium and copper using Azolla filiculoidesLam. in a hydroponic system. Water and Environment Journal, n/a-n/a.

Van Nevel, L., Mertens, J., Staelens, J., De Schrijver, A., Tack, F. M. G., De Neve, S., Meers, E., and Verheyen, K. 2011. Elevated Cd and Zn uptake by aspen limits the phytostabilization potential compared to five other tree species. Ecol Eng 37: 1072-1080.

van Schaik, J. W. J., Kleja, D. B., and Gustafsson, J. P. 2010. Acid-base and copper-binding properties of three organic matter fractions isolated from a forest floor soil solution. Geochim Cosmochim Ac 74: 1391-1406.

Vaseem, H. and Banerjee, T. K. 2012. Phytoremediation of the toxic effluent generated during recovery of precious metals from polymetallic sea nodules. Int J Phytoremediat 14: 457-466.

Vega, F. A., Andrade, M. L., and Covelo, E. F. 2010. Influence of soil properties on the sorption and retention of cadmium, copper and lead, separately and together, by 20 soil horizons: Comparison of linear regression and tree regression analyses. J Hazard Mater 174: 522-533.

Venkatesh, N. M. and Vedaraman, N. 2012. Remediation of soil contaminated with copper using Rhamnolipids produced from Pseudomonas aeruginosa MTCC 2297 using waste frying rice bran oil. Ann Microbiol 62: 85-91.

Vert, G., Barberon, M., Zelazny, E., Seguela, M., Briat, J. F., and Curie, C. 2009. Arabidopsis IRT2 cooperates with the high-affinity iron uptake system to maintain iron homeostasis in root epidermal cells. Planta 229: 1171-1179.

Vitousek, P. M., Naylor, R., Crews, T., David, M. B., Drinkwater, L. E., Holland, E., Johnes, P. J., Katzenberger, J., Martinelli, L. A., Matson, P. A., Nziguheba, G., Ojima, D., Palm, C. A., Robertson, G. P., Sanchez, P. A., Townsend, A. R., and Zhang, F. S. 2009. Nutrient imbalances in agricultural development. Science 324: 1519-1520.

Vurro, E., Ruotolo, R., Ottonello, S., Elviri, L., Maffini, M., Falasca, G., Zanella, L., Altamura, M. M., and di Toppi, L. S. 2011. Phytochelatins govern zinc/copper homeostasis and cadmium detoxification in Cuscuta campestris parasitizing Daucus carota. Environ Exp Bot 72: 26-33.

Wang, C., Yang, Z. F., Yuan, X. Y., Browne, P., Chen, L. X., and Ji, J. F. 2013. The influences of soil properties on $\mathrm{Cu}$ and $\mathrm{Zn}$ availability in soil and their transfer to wheat (Triticum aestivum L.) in the Yangtze River delta region, China. Geoderma 193: 131-139.

Wang, H. O. and Zhong, G. R. 2011. Effect of organic ligands on accumulation of copper in hyperaccumulator and nonaccumulator Commelina communis. Biol Trace Elem Res 143: 489-499.

Waters, B. M. and Grusak, M. A. 2008. Whole-plant mineral partitioning throughout the life cycle in Arabidopsis thaliana ecotypes Columbia, Landsberg erecta, Cape Verde Islands, and the mutant line ysl1ysl3. New Phytol 177: 389-405.

White, P. J. and Brown, P. H. 2010. Plant nutrition for sustainable development and global health. Ann Bot-London 105: 1073-1080.

Widodo, B., Broadley, M. R., Rose, T., Frei, M., Pariasca-Tanaka, J., Yoshihashi, T., Thomson, M., Hammond, J. P., Aprile, A., Close, T. J., Ismail, A. M., and Wissuwa, M. 2010. Response to zinc deficiency of two rice lines with contrasting tolerance is determined by root growth maintenance and organic acid exudation rates, and not by zinc-transporter activity. New Phytol 186: $400-414$.

Wilkinson, S., Van Genderen, E., Green, A., and Grund, S. 2011. Zinc - A sustainable metal. World of Metallurgy - ERZMETALL 64: 118-122.

Wong, C. K. E. and Cobbett, C. S. 2009. HMA P-type ATPases are the major mechanism for root-to-shoot $\mathrm{Cd}$ translocation in Arabidopsis thaliana. New Phytol 181: 71-78.

Wu, B. and Becker, J. S. 2012. Imaging techniques for elements and element species in plant science. Metallomics : Integrated Biometal Science 4: 403-416.

Wu, C. F., Luo, Y. M., and Zhang, L. M. 2010. Variability of copper availability in paddy fields in relation to selected soil properties in southeast China. Geoderma 156: 200-206.

Wu, L. H., Li, Z., Akahane, I., Liu, L., Han, C. L., Makino, T., Luo, Y. M., and Christie, P. 2012a. Effects of organic amendments on $\mathrm{Cd}, \mathrm{Zn}$ and $\mathrm{Cu}$ 
bioavailability in soil with repeated phytoremediation by sedum plumbizincicola. Int J Phytoremediat 14: 1024-1038.

Wu, L. H., Li, Z., Han, C. L., Liu, L., Teng, Y., Sun, X. H., Pan, C., Huang, Y. J., Luo, Y. M., and Christie, P. 2012b. Phytoremediation of soil contaminated with cadmium, copper and polychlorinated biphenyls. Int J Phytoremediat 14: $570-584$.

Xu, J., Tian, Y. S., Peng, R. H., Xiong, A. S., Zhu, B., Jin, X. F., Gao, J. J., Hou, X. L., and Yao, Q. H. 2009. Yeast copper-dependent transcription factor ACE1 enhanced copper stress tolerance in Arabidopsis. Bmb Rep 42: 752-757.

Xu, W. F., Shi, W. M., Yan, F., Zhang, B. A., and Liang, J. S. 2011. Mechanisms of cadmium detoxification in cattail (Typha angustifolia L.). Aquat Bot $\mathbf{9 4}$, 37-43.

Xue, P. Y., Li, G. X., Liu, W. J., and Yan, C. Z. 2010. Copper uptake and translocation in a submerged aquatic plant Hydrilla verticillata (L.f.) Royle. Chemosphere 81: 1098-1103.

Yang, J. X., Liu, Y., and Ye, Z. H. 2012. Root-Induced changes of pH, Eh, Fe(II) and fractions of $\mathrm{Pb}$ and $\mathrm{Zn}$ in rhizosphere soils of four wetland plants with different radial oxygen losses. Pedosphere 22: 518-527.

Yao, Y. N., Xu, G., Mou, D. L., Wang, J. R., and Ma, J. B. 2012. Subcellular Mn compartation, anatomic and biochemical changes of two grape varieties in response to excess manganese. Chemosphere 89: 150-157.

Yi, Y. J., Yang, Z. F., and Zhang, S. H. 2011. Ecological risk assessment of heavy metals in sediment and human health risk assessment of heavy metals in fishes in the middle and lower reaches of the Yangtze River basin. Environ Pollut 159: 2575-2585.

Yuan, M., Li, X. H., Xiao, J. H., and Wang, S. P. 2011. Molecular and functional analyses of COPT/Ctr-type copper transporter-like gene family in rice. Bmc Plant Biol 11.

Zhang, X. C., Lin, L., Chen, M. Y., Zhu, Z. Q., Yang, W. D., Chen, B., Yang, X. E., and An, Q. L. 2012a. A nonpathogenic Fusarium oxysporum strain enhances phytoextraction of heavy metals by the hyperaccumulator Sedum alfredii Hance. J Hazard Mater 229: 361-370.
Zhang, X. F., Xia, H. P., Li, Z. A., Zhuang, P., and Gao, B. 2010. Potential of four forage grasses in remediation of $\mathrm{Cd}$ and $\mathrm{Zn}$ contaminated soils. Bioresource Technol 101: 2063-2066.

Zhang, Y., Xu, Y. H., Yi, H. Y., and Gong, J. M. 2012b. Vacuolar membrane transporters OsVIT1 and OsVIT2 modulate iron translocation between flag leaves and seeds in rice. Plant J 72: 400-410.

Zhao, F. J., Ma, J. F., Meharg, A. A., and McGrath, S. P. 2009. Arsenic uptake and metabolism in plants. New Phytol 181: 777-794.

Zhao, H. J., Wu, L. Q., Chai, T. Y., Zhang, Y. X., Tan, J. J., and Ma, S. W. 2012. The effects of copper, manganese and zinc on plant growth and elemental accumulation in the manganese-hyperaccumulator Phytolacca americana. $J$ Plant Physiol 169: 1243-1252.

Zhao, K. L., Liu, X. M., Zhang, W. W., Xu, J. M., and Wang, F. 2011. Spatial dependence and bioavailability of metal fractions in paddy fields on metal concentrations in rice grain at a regional scale. J Soil Sediment 11: 1165 1177 .

Zheng, L. Q., Yamaji, N., Yokosho, K., and Ma, J. F. 2012. YSL16 is a phloem-localized transporter of the copper-nicotianamine complex that is responsible for copper distribution in rice. Plant Cell 24: $3767-$ 3782.

Zhong, X. L., Zhou, S. L., Zhu, Q., and Zhao, Q. G. 2011. Fraction distribution and bioavailability of soil heavy metals in the Yangtze River Delta-A case study of Kunshan City in Jiangsu Province, China. J Hazard Mater 198, 13-21.

Zimmermann, M., Clarke, O., Gulbis, J. M., Keizer, D. W., Jarvis, R. S., Cobbett, C. S., Hinds, M. G., Xiao, Z. G., and Wedd, A. G. 2009. Metal binding affinities of Arabidopsis zinc and copper transporters: Selectivities match the relative, but not the absolute, affinities of their amino-terminal domains. Biochemistry-Us 48: 11640-11654.

Zorrig, W., Abdelly, C., and Berthomieu, P. 2011. The phylogenetic tree gathering the plant $\mathrm{Zn} / \mathrm{Cd} / \mathrm{Pb} / \mathrm{Co} \mathrm{P}-1 \mathrm{~B}$-ATPases appears to be structured according to the botanical families. $\mathrm{Cr}$ Biol 334: 863871. 